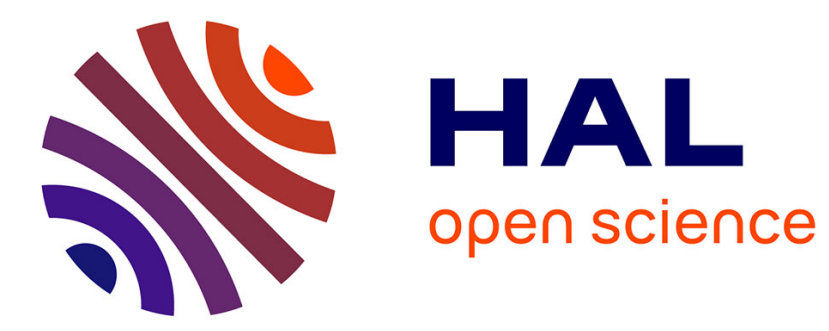

\title{
Predicting the global warming potential of agro-ecosystems
}

S. Lehuger, B. Gabrielle, E. Larmanou, P. Laville, P. Cellier, B. Loubet

\section{To cite this version:}

S. Lehuger, B. Gabrielle, E. Larmanou, P. Laville, P. Cellier, et al.. Predicting the global warming potential of agro-ecosystems. Biogeosciences Discussions, 2007, 4 (2), pp.1059-1092. hal-00330234

\section{HAL Id: hal-00330234 \\ https://hal.science/hal-00330234}

Submitted on 4 Apr 2007

HAL is a multi-disciplinary open access archive for the deposit and dissemination of scientific research documents, whether they are published or not. The documents may come from teaching and research institutions in France or abroad, or from public or private research centers.
L'archive ouverte pluridisciplinaire HAL, est destinée au dépôt et à la diffusion de documents scientifiques de niveau recherche, publiés ou non, émanant des établissements d'enseignement et de recherche français ou étrangers, des laboratoires publics ou privés. 
Biogeosciences Discuss., 4, 1059-1092, 2007

www.biogeosciences-discuss.net/4/1059/2007/

(c) Author(s) 2007. This work is licensed

under a Creative Commons License.

Biogeosciences Discussions is the access reviewed discussion forum of Biogeosciences

\section{Predicting the global warming potential of agro-ecosystems}

S. Lehuger, B. Gabrielle, E. Larmanou, P. Laville, P. Cellier, and B. Loubet

INRA, AgroParisTech, UMR 1091 Environment and Arable Crops, 78850 Thiverval-Grignon, France

Received: 14 March 2007 - Accepted: 26 March 2007 - Published: 4 April 2007

Correspondence to: S. Lehuger (simon.lehuger@grignon.inra.fr)
BGD

4, 1059-1092, 2007

Global warming potential of agro-ecosystems

S. Lehuger et al.

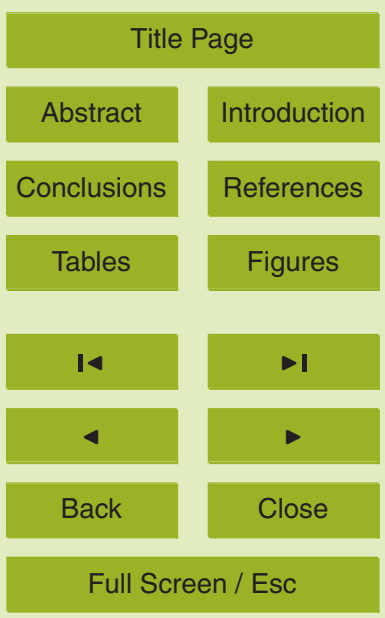

Printer-friendly Version

Interactive Discussion 


\section{Abstract}

Nitrous oxide, carbon dioxide and methane are the main biogenic greenhouse gases (GHG) contributing to the global warming potential (GWP) of agro-ecosystems. Evaluating the impact of agriculture on climate thus requires a capacity to predict the net ex-

5 changes of these gases in an integrated manner, as related to environmental conditions and crop management. Here, we used two year-round data sets from two intensivelymonitored cropping systems in northern France to test the ability of the biophysical crop model CERES-EGC to simulate GHG exchanges at the plot-scale. The experiments involved maize and rapeseed crops on a loam and rendzina soils, respectively. The

mas subsequently extrapolated to predict $\mathrm{CO}_{2}$ and $\mathrm{N}_{2} \mathrm{O}$ fluxes over an entire crop rotation. Indirect emissions (IE) arising from the production of agricultural inputs and from cropping operations were also added to the final GWP. One experimental site (involving a wheat-maize-barley rotation on a loamy soil) was a net source of GHG with a GWP of $350 \mathrm{~kg} \mathrm{CO}_{2}-\mathrm{C} \mathrm{eq} \mathrm{ha}^{-1} \mathrm{yr}^{-1}$, of which $75 \%$ were due to IE and $25 \%$ to direct $\mathrm{N}_{2} \mathrm{O}$ emissions. The other site (involving an oilseed rape-wheat-barley rotation on a rendzina) was a net sink of $\mathrm{GHG}$ for $-250 \mathrm{~kg} \mathrm{CO}_{2}-\mathrm{Ceq} \mathrm{ha}^{-1} \mathrm{yr}^{-1}$, mainly due to a higher predicted $\mathrm{C}$ sequestration potential and $\mathrm{C}$ return from crops. Such modelling approach makes it possible to test various agronomic management scenarios, in order to design productive agro-ecosystems with low global warming impact.

\section{Introduction}

Agricultural soils contribute about $15 \%$ of global greenhouse gases (GHG) emissions, a share expected to rise in the future due to the increasing land use and management intensity of agriculture worldwide (Duxbury et al., 1993; Gitz and Ciais, 2003). In the case of arable crops, these emissions include both exchanges of GHG in the cultivated field, and the upstream (indirect) emissions arising from the production of agricultural inputs (fertilizers, pesticides and lime), fuel combustion and use of machinery on the

BGD

4, 1059-1092, 2007

\section{Global warming potential of agro-ecosystems}

S. Lehuger et al.

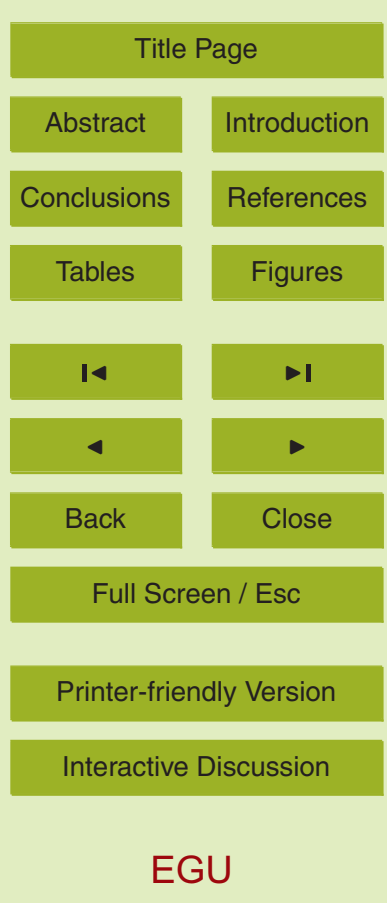


farm. Indirect emissions of GHG may contribute as much as half of the total GHG budget of agricultural crops (Robertson et al., 2000; Mosier et al., 2005). Thus, this term provides good leverage to mitigate their impact on global warming (West and Marland, 2002). The global GHG balance may be expressed as the global warming potential 5 (GWP) of an agro-ecosystem considered, in $\mathrm{CO}_{2}$ equivalents, using the GWPs of all the trace gases with radiative forcing (IPCC, 2001).

The direct emissions of GHG by agro-ecosystems are made up of three terms: emissions of nitrous oxide, net carbon fluxes between soil-plant systems and the atmosphere, and methane exchanges. Nitrous oxide $\left(\mathrm{N}_{2} \mathrm{O}\right)$ is produced by soil micro10 organisms via the processes of nitrification and denitrification (Wrage et al., 2001). Arable soils are responsible for $60 \%$ of the global anthropogenic emissions of $\mathrm{N}_{2} \mathrm{O}$ (IPCC, 2001), and their source strength primarily depends on the fertilizer $\mathrm{N}$ inputs necessary for crop production. Other environmental factors regulate these emissions: soil temperature, soil moisture, soil $\mathrm{NO}_{3}^{-}$and $\mathrm{NH}_{4}^{+}$concentrations, and the availability 15 of organic $\mathrm{C}$ substrate to micro-organisms (Hutchinson and Davidson, 1993). The effect of these factors results in a large spatial and temporal variability of $\mathrm{N}_{2} \mathrm{O}$ emissions (Kaiser and Ruser, 2000; Jungkunst et al., 2006). The second term in the GHG balance, net $C$ exchanges, is generally taken as the variations in topsoil organic $C$ content (SOC). These variations reflect the balance between $C$ inputs to the agro-ecosystems, via crop residue return, root deposition and organic amendments, and soil organic matter mineralization. Lastly, non-flooded cropland are usually considered as a weak methane-sink that mitigates the global warming potential (GWP) of cropping systems by $1 \%$ to $3 \%$ (Robertson et al., 2000, Mosier et al., 2005). Neglecting $\mathrm{CH}_{4}$ exchanges, which is justified for non-flooded cropland in temperate climate, implies that only three terms contribute in the net GWP: soil organic carbon changes, $\mathrm{N}_{2} \mathrm{O}$ emissions, and indirect emissions.

Various agricultural practices impact the GHG balance of agro-ecosystems. Some of them may first enhance the carbon sink-strength of soils: conversion to no-tillage practices, the introduction of catch crops, and the incorporation of crop residues into

BGD

4, 1059-1092, 2007

\section{Global warming potential of agro-ecosystems}

S. Lehuger et al.

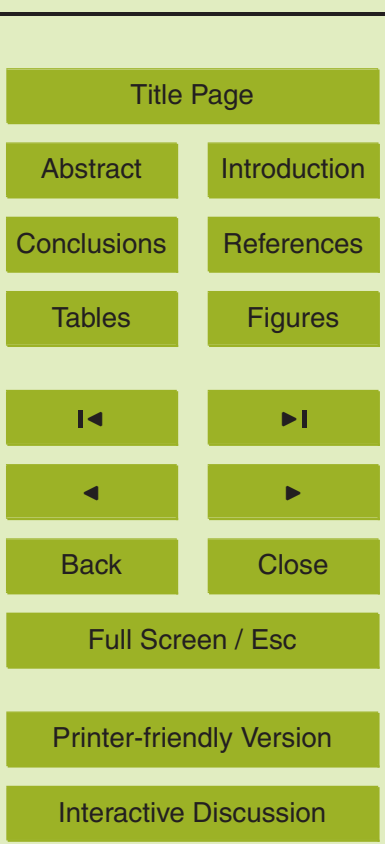

EGU 
the topsoil were shown to lead to possible $\mathrm{C}$ sequestration into the organic carbon pool of the agricultural soils (Smith et al., 2001; Arrouays et al., 2002). The evaluation of candidate agricultural practices to reduce the GWP of agro-ecosystems should encompass indirect and direct emissions of all GHG, to avoid trade-off effects. For in5 stance, because the $\mathrm{C}$ and $\mathrm{N}$ biogeochemical cycles are interconnected, $\mathrm{CH}_{4}$ and $\mathrm{N}_{2} \mathrm{O}$ emissions may offset the beneficial $\mathrm{C}$ storage associated with practices targeting at $\mathrm{C}$ sequestration (Six et al., 2004; Desjardins et al., 2005; Li et al., 2005).

In the literature, the GWP of agro-ecosystems is either calculated to assess the effect of the conversion to a new management practice (e.g. no-till, catch crops, farmyard 10 manure application, or land use change; Robertson et al., 2000; Bhatia et al., 2005; Mosier et al., 2005), or for inclusion into the life cycle assessment of a crop-derived product. These include biofuels, animal feed, or human food (Kim and Dale, 2005; Gabrielle and Gagnaire, 2007). Direct GHG emissions may be either estimated from direct field measurements (Robertson et al., 2000; Bhatia et al., 2005; Mosier et al., 2005), or by using biogeochemical models simulating GHG emissions (Del Grosso et al., 2005; Desjardins et al., 2005; Pathak et al., 2005). Most agro-ecosystems have a positive net GWP (meaning they enhance global warming), but this trend is mainly controlled by the $\mathrm{C}$ storage potential of the soil. In the US Midwest, Robertson et al. (2000) measured the GWP of an annual crop rotation (maize-soybean-wheat) as 40 In Colorado, for rainfed crops under no-till practices, Mosier et al. (2005) measured a topsoil C-storage of about $300 \mathrm{~kg} \mathrm{CO}_{2}-\mathrm{Ceq} \mathrm{ha}^{-1} \mathrm{yr}^{-1}$ in perennial, rainfed crops under no-till, which offset the other terms in the GHG balance and resulted in a negative net GWP of $-85 \mathrm{~kg} \mathrm{CO}_{2}-\mathrm{C}$ eq ha ${ }^{-1} \mathrm{yr}^{-1}$.

The various terms of the net GWP should be predicted with similar accuracy. Indirect emissions may be easily calculated thanks to databases of life cycle inventories (West and Marland, 2002; Nemecek et al., 2003), but direct field emissions of $\mathrm{N}_{2} \mathrm{O}$ and $\mathrm{C}$ storage in soil are extremely dependant of pedoclimatic conditions and agricultural management practices. To take into account these sources of variability, and to de-
BGD

4, 1059-1092, 2007

\section{Global warming potential of agro-ecosystems}

S. Lehuger et al.

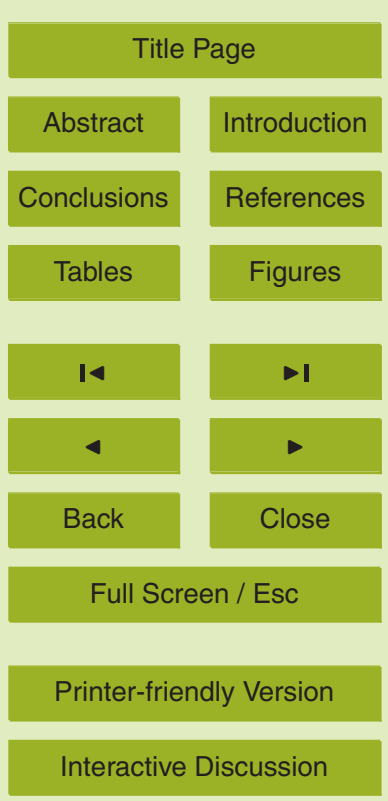

EGU 
vise mitigation strategies, the processes occurring in the soil-crop-atmosphere system should be modelled simultaneously, together with the effect of agricultural practices. In the past, modelling approaches were developed in parallel either by agronomists seeking to predict crop growth and yields in relation to their management (Boote et al.,

5 1996), or by ecologists focusing on biogeochemical cycles and in particular mineralization, nitrification and denitrification in soils (e.g., Li et al., 2005). With the increasing interest for the prediction of trace gas emissions from arable soils (or pollutants in general), both approaches should be linked together in a more holistic perspective (Gijsman et al., 2002; Zhang et al., 2002). The CERES-EGC model was designed following 10 this philosophy to estimate site-and-management specific environmental balance, or regionalised inventories of trace gas emissions (Gabrielle et al., 2006).

The objectives of this work were: $\mathrm{i} /$ to test the CERES-EGC crop model with experimental data from two cropping systems representative of northern France: a maizewheat-barley rotation on a loamy loess soil and a rapeseed-wheat-barley rotation on a 15 rendzina, and ii/ to apply the model to assess the GWP of these two cropping systems, including direct and indirect emissions of GHG.

\section{Materials and methods}

\subsection{Experimental data}

\subsubsection{Field sites}

The field experiments were carried out at two locations in northern France, at Rafidin $\left(48.5^{\circ} \mathrm{N}, 2.15^{\circ} \mathrm{E}\right)$ in the Champagne region in 1994-1995 (Gosse et al., 1999), and at Grignon near the city of Paris $\left(48.9^{\circ} \mathrm{N}, 1.95^{\circ} \mathrm{E}\right)$ in 2005.

In Rafidin, the soil was a grey rendzina overlying a subsoil of mixed compact and cryoturbed chalk. The topsoil $(0-30 \mathrm{~cm})$ has a clay loam texture, with $(31 \%$ clay and

BGD

4, 1059-1092, 2007

\section{Global warming potential of agro-ecosystems}

S. Lehuger et al.

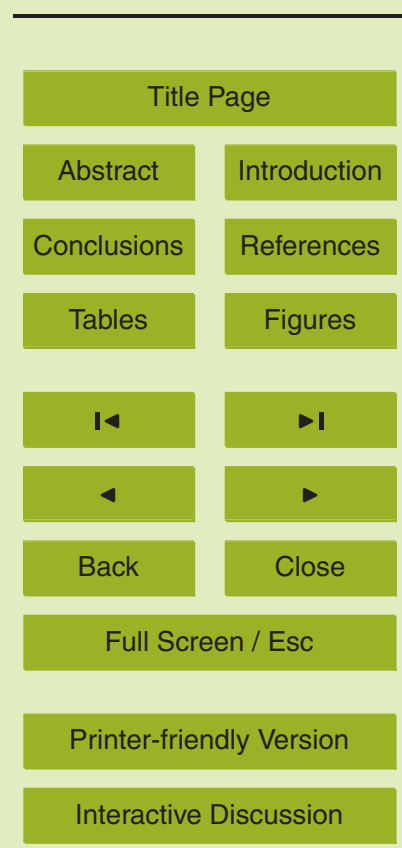

EGU 
density of $1.23 \mathrm{~g} \mathrm{~cm}^{-3}$. Other soil properties are available in the dedicated world wild web server on the following address: http://www-egc.grignon.inra.fr.

In Grignon, the soil was a silt loam with $18.9 \%$ clay and $71.3 \%$ silt in the topsoil. In the top $15 \mathrm{~cm}$, organic carbon content was $15.9 \mathrm{~g} \mathrm{~kg}^{-1}$, the $\mathrm{pH}$ (water) was 7.6 and the 5 bulk density $1.30 \mathrm{~g} \mathrm{~cm}^{-3}$.

The Rafidin site involved a winter rapeseed - winter wheat - winter barley rotation, and the measurements essentially took place during the rapeseed growing cycle, from its sowing on 9 Sept., 1994 to its harvest on 11 July, 1995. Three fertilizer N treatments (N0=0 kg N ha ${ }^{-1}, \mathrm{~N} 1=135 \mathrm{~kg} \mathrm{Nha}^{-1}$ and N2 $=270 \mathrm{~kg} \mathrm{~N} \mathrm{ha}^{-1}$ ) were established on $1030 \times 30 \mathrm{~m}$ blocks arranged in a split-plot design with three replicates (see Table 1). For this site, we only calculated the GWP of the N1 and N2 treatments, which have a potential agronomic value, and the rotations we simulated were only different regarding the fertilizer $\mathrm{N}$ inputs on the rapeseed crop. The other crops in the rotation (wheat and barley) were managed identically in the $\mathrm{N} 1$ and $\mathrm{N} 2$ rotations.

15 At the Grignon site, a maize - winter wheat - winter barley rotation was monitored, with more detailed measurements during the maize growing season in 2005 . The maize was sown on 9 May 2005 and harvested on 28 September 2005. A mustard was planted following the harvest of barley the year before to serve as a catch crop to reduce nitrate leaching. Dairy cow slurry was applied between the harvest of barley and 20 the planting of mustard on 31 August 2004 . The maize was fertilized with $70 \mathrm{~kg} \mathrm{~N} \mathrm{ha}^{-1}$ of urea and $70 \mathrm{~kg} \mathrm{Nha}^{-1}$ of ammonium nitrate on the sowing date (see Table 1).

\subsubsection{Soil and crop measurements}

Soil mineral nitrogen content $\left(\mathrm{NO}_{3}^{-}\right.$and $\left.\mathrm{NH}_{4}^{+}\right)$and moisture content were monitored in the following layers: $0-15 \mathrm{~cm}, 15-30 \mathrm{~cm}, 30-60 \mathrm{~cm}$ and $60-90 \mathrm{~cm}$ at Grignon, and 0-30 cm, 30-60 cm, 60-90 cm, and $90-120 \mathrm{~cm}$ at Rafidin. Soil samples were taken in triplicates with an automatic (Rafidin) or manual (Grignon) auger every 2 to 4 weeks, and analysed for moisture content and mineral $\mathrm{N}$. The latter involved an extraction of

BGD

4, 1059-1092, 2007

\section{Global warming potential of agro-ecosystems}

S. Lehuger et al.

Title Page

Abstract

Introduction

Conclusions

Tables

References

Figures

14

4

Back

Close

Full Screen / Esc

Printer-friendly Version

Interactive Discussion 
soil samples with $1 \mathrm{M} \mathrm{KCl}$ and colorimetric analysis of the supernatant. In both sites, soil moisture and temperature were also continuously recorded using TDR (Time Domain Reflectrometry, Campbell Scientific, Logan, Utah, USA) and thermocouples. Soil bulk density was measured once in each site, using steel rings.

$5 \quad$ For both experiments, plants were collected every 2 to 4 weeks, and separated into leaves, stems, ears or pods, and roots. Leaf area index was measured with an optical leaf area meter or analysis of leaf scans. The plant samples were dried for $48 \mathrm{~h}$ at $80^{\circ} \mathrm{C}$ and weighted, and analysed for $\mathrm{C}, \mathrm{N}, \mathrm{P}$ and $\mathrm{K}$ content by flash combustion.

\subsubsection{Trace gas fluxes and micrometeorological measurements}

10 At the Grignon and Rafidin sites, daily climatic data were recorded with an automatic meteorological station, including maximum and minimum daily air temperatures $\left({ }^{\circ} \mathrm{C}\right)$, rainfall $\left(\mathrm{mm} \mathrm{day}^{-1}\right)$, solar radiation $\left(\mathrm{MJ} \mathrm{m}^{2} \mathrm{day}^{-1}\right)$ and wind speed $\left(\mathrm{m} \mathrm{s}^{-1}\right)$.

At Grignon, the measurements of $\mathrm{CO}_{2}$ fluxes at the field scale were carried out in the framework of the CarboEurope integrated project (European Commission Framework $\mathrm{VI}$ research programme). Water vapour and $\mathrm{CO}_{2}$ fluxes were measured using the eddy covariance method above the maize canopy. Wind speed was monitored with a three-dimensional sonic anemometer (R3-50, Gill Solent, Lymington, UK), and $\mathrm{CO}_{2}$ concentration with a $20 \mathrm{~Hz}$ infrared gas analyser ( $\mathrm{Li}-7500$, Li-Cor Inc., Lincoln, NE, USA) located on a mast at two meters above the canopy. Daily net ecosystem car20 bon dioxide exchange $\left(\mathrm{g} \mathrm{C} \mathrm{m}^{-2}\right.$ day $\left.^{-1}\right)$, and its daily evapotranspiration $\left(\mathrm{mm} \mathrm{m}^{-2}\right.$ day $\left.^{-1}\right)$ were calculated by integrating the 30-min fluxes determined by the micrometeorological measurements over each day. The eddy covariance technique usually produces gaps in the $1 / 2$ hourly $\mathrm{C}$ flux data, making it necessary to fill the missing values before integration at the daily time scale. Here, we used non-linear regression methods to 25 fill the missing NEP data. Daytime and nighttime data were separately calculated with a photosynthesis model based on a Misterlich function for daytime gaps and with a respiration model for the following nighttime period (Falge et al., 2001).

At Rafidin, there were no micrometeorological measurements of $\mathrm{CO}_{2}$ exchanges.

\section{Global warming potential of agro-ecosystems}

S. Lehuger et al.

Title Page

Abstract Introduction

Conclusions

Tables

References

Figures

14

$\rightarrow$

4

Back

Close

Full Screen / Esc

Printer-friendly Version

Interactive Discussion 
Nitrous oxide emissions were monitored by the static chamber method using circular chambers $\left(0.2 \mathrm{~m}^{2}\right)$, with 8 replicates. On each sampling date, the chambers were closed with an airtight lid, and the head space was sampled 4 times over a period of $2 \mathrm{~h}$. The gas samples were analysed in the laboratory by gas chromatography. The 5 measurements were done every 1-3 weeks between September, 1994 and April, 1995 (Gosse et al., 1999).

At Grignon, $\mathrm{N}_{2} \mathrm{O}$ emissions were measured with three automatic chambers $(55 \mathrm{~L}$, $0.5 \mathrm{~m}^{2}$ ). The chambers were sequentially closed during $15 \mathrm{~min}$ and the complete cycle for the three chambers was then fixed to $45 \mathrm{~min}$. The $\mathrm{N}_{2} \mathrm{O}$ concentrations were 10 measured using an infrared gas analyser $\left(\mathrm{N}_{2} \mathrm{O}\right.$ Analyser $46 \mathrm{C}$, Thermo Scientific Inc., Waltham, MA, USA) which was connected on line with the chambers. Air was pumped from the chamber to the gas analyser and injected again after the analysis to the chambers. Nitrous oxide fluxes were calculated from the slope of the gas accumulation rate. The electric jacks used to open and close the chambers and the solenoid valves were 15 controlled by a Campbell data logger (CR23X, Logan, Campbell Scientific, Utah, USA) that recorded the $\mathrm{N}_{2} \mathrm{O}$ concentration every $10 \mathrm{~s}$. Nitrous oxide emissions were monitored for 31 days from 13 May 2005, to 12 June 2005. During this period, the mean value of the emissions was $5 \mathrm{~g} \mathrm{Nha}^{-1} \mathrm{~d}^{-1}$, and the spatial coefficient of variation for the three chambers was quite large $(79 \%)$.

\subsection{The CERES-EGC model}

CERES-EGC was adapted from the CERES suite of soil-crop models (Jones and Kiniry, 1986), with a focus on the simulation of environmental outputs such nitrate leaching, emissions of $\mathrm{N}_{2} \mathrm{O}$, ammonia, and nitric oxide (Gabrielle et al., 2006). It can therefore be used as an agronomic tool to improve the management of major arable 25 crops, based on crop productivity and environmental criteria. The model simulates the cycles of water, carbon and nitrogen with three main sub-models.

A physical sub-model simulates the transfer of heat, water and nitrate down the soil profile. The evapotranspiration is modelled in relation with climatic demand, and

\section{BGD}

4, 1059-1092, 2007

\section{Global warming potential of agro-ecosystems}

S. Lehuger et al.

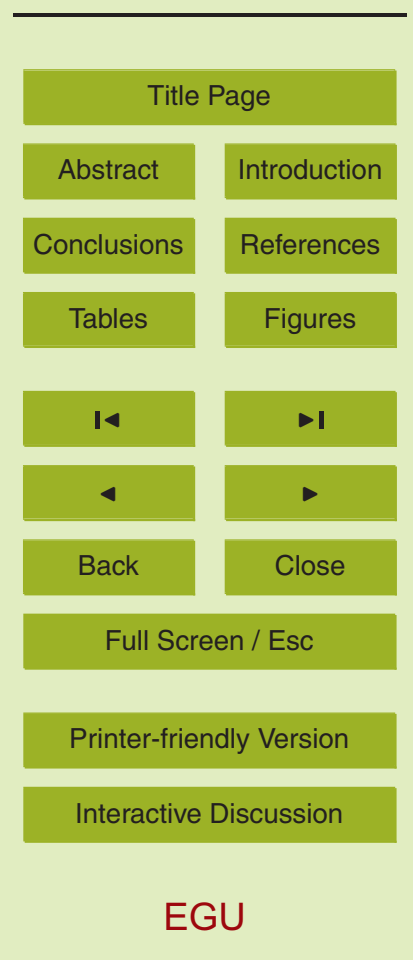


according to Ritchie's (1972) model. Soil water content and fluxes are determined by a semi-empirical Darcy's law in the soil profile (Gabrielle et al., 1995).

A microbiological sub-model adapted from the NCSOIL model (Molina et al., 1983) simulates the turnover of the soil organic matter in the plow layer. Decomposition, 5 mineralization and $\mathrm{N}$-immobilization are modelled with three pools of organic matter (OM): the labil OM, the microbial biomass and the humads. Kinetic rate constants define the $\mathrm{C}$ and $\mathrm{N}$ flows between the different pools.

A biological sub-model simulates the growth and the phenology of the crops. The increase of daily biomass is controlled by net photosynthesis which is modelled by 10 a Monteith approach. The production of biomass $\left(\mathrm{g} \mathrm{DM} \mathrm{m}^{-2}\right.$ day $\left.^{-1}\right)$ is proportional to the amount of photosynthetically active radiation (PAR, $\mathrm{MJ} \mathrm{m}^{-2}$ day $^{-1}$ ) intercepted by the crop canopy, using the concept of radiation use efficiency (RUE, gDM MJ $\mathrm{g} \mathrm{m}^{-2}$ ). Interception of PAR depends on leaf area index, and is based on Beer's law of diffusion in turbid media.

15 Direct field emissions of $\mathrm{CO}_{2}, \mathrm{~N}_{2} \mathrm{O}, \mathrm{NO}$ and $\mathrm{NH}_{3}$ into the atmosphere are simulated with different trace gas modules. Here, we focus on gas emissions with global warming potential, i.e. $\mathrm{CO}_{2}$ and $\mathrm{N}_{2} \mathrm{O}$.

Carbon dioxide exchanges between soil-plant system and the atmosphere are modelled via the net photosynthesis and SOC mineralization processes. Net primary production (NPP) is simulated by the crop growth module while heterotrophic respiration (Rs) is deduced from the SOC mineralization rates calculated by the microbiological sub-model. The net ecosystem production (NEP), which is calculated as NPP minus Rs, may be computed on a daily basis and directly tested against the net ecosystem exchanges measured by eddy covariance. The confrontation between the daily rates of simulated and measured NEP provides a good opportunity to test the simulation of C dynamics by the soil-crop model.

CERES-EGC uses the semi-empirical model NOE (Hénault et al., 2005) for simulating the $\mathrm{N}_{2} \mathrm{O}$ production in the soil through both the nitrification and the denitrification pathways. Denitrification component is derived from the NEMIS model (Hénault and

\section{BGD}

4, 1059-1092, 2007

\section{Global warming potential of agro-ecosystems}

S. Lehuger et al.

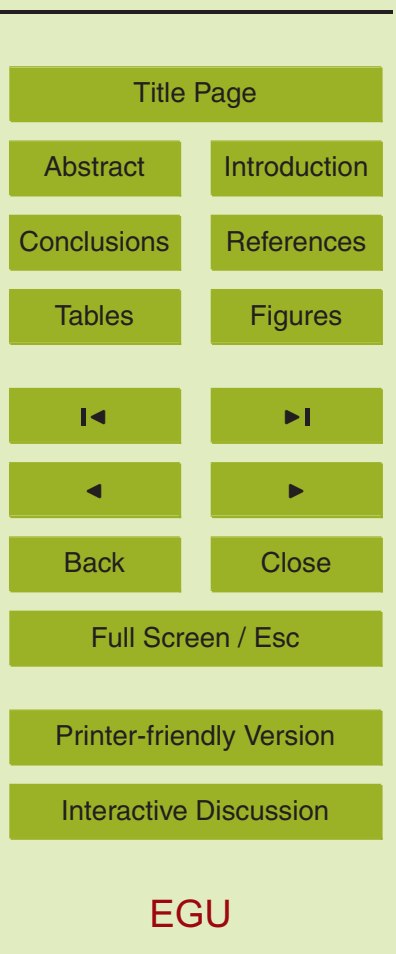


Germon, 2000) that calculates the denitrification as the product of a potential rate with three unitless factors related to soil water content, nitrate content and temperature. Nitrification is modelled as a Michaëlis-Menten reaction with $\mathrm{NH}_{4}^{+}$as substrate that additionally is controlled by response functions of the soil water content and temperature.

5 Nitrous oxide emissions resulting from the two processes are soil-specific proportions of total denitrification and nitrification pathways.

CERES-EGC runs on a daily time step and requires input data for agricultural management practices, climatic variables (mean air temperature, daily rain and Penman potential evapotranspiration), and soil properties.

\subsection{The indirect GHG emissions}

The $\mathrm{GHG}$ emissions $\left(\mathrm{CO}_{2}, \mathrm{~N}_{2} \mathrm{O}\right.$ and $\left.\mathrm{CH}_{4}\right)$ associated with input production and agricultural operations were calculated from the Ecoinvent life cycle inventory database (Nemecek et al., 2003). The inventory of elementary management operations comprises soil tillage, fertilisation, sowing, plant protection, harvest and transport, and may be translated in terms of GHG emissions thanks to emission factors. Similarly, the production of agricultural inputs (fertilizers, pesticides, seeds and agricultural machinery) induces GHG emissions that arise mainly from fossil fuel combustion, and were included in the indirect emissions.

\subsection{Model evaluation}

20 Two statistical indicators were used to evaluate the performance of the model to fit with the observed data. Mean deviation (MD) was defined as: $M D=E\left(O_{i}-S_{i}\right)$ and the rootmean squared error as: RMSE $=\left(E\left[\left(O_{i}-S_{i}\right)^{2}\right]\right)^{1 / 2}$ where $O_{i}$ and $S_{i}$ are the time series of the observed and the simulated data, and $E$ denotes the expectancy (Smith et al., 1996).

\section{Global warming potential of agro-ecosystems}

S. Lehuger et al.

\section{Title Page}

Abstract Introduction

Conclusions

Tables References

Figures

14

Back

Close

\section{Full Screen / Esc}

Printer-friendly Version

Interactive Discussion 


\section{Results and discussion}

BGD

3.1 Model testing

\subsubsection{Crop growth}

At Grignon, the crop growth was well simulated, as reported in Fig. 1. The time course of total above ground biomass was correctly captured by the model, along with its partitioning into leaves, stems and ears. The final simulated grain yield ( $8.8 \mathrm{t}$ dry matter $\left.\mathrm{DM} \mathrm{ha}^{-1}\right)$ was close to the observed value $\left(8.7 \mathrm{tDM} \mathrm{ha}^{-1}\right)$. The $\mathrm{LAl}$ increase during the vegetative period was well predicted, but the senescence phase was a little too early in comparison with the observations (Fig. 1b).

10 At the Rafidin site, CERES-EGC provided good simulations of rapeseed growth for the $\mathrm{N} 1$ and $\mathrm{N} 2$ treatments (Fig. 2). The simulated patterns of biomass, LAI and N content variations matched the observations over the entire growing cycle. Final grain yields were correctly estimated, with a simulated value of $3.8 \mathrm{tDM} \mathrm{ha}^{-1}$ and an observed one of $4.1 \mathrm{tDM} \mathrm{ha}^{-1}$ for $\mathrm{N} 1$, and an exact match at $4.9 \mathrm{tDM} \mathrm{ha}^{-1}$ for $\mathrm{N} 2$. For the 15 No treatment (unfertilized), the model overestimated LAl by a factor of 2 throughout the growing season, but total above ground biomass was underestimated by about $25 \%$ when compared to the data (not shown). For this treatment, the simulated $\mathrm{N}$ stress was too high at the end of the crop's growing cycle to allow sufficient grain filling, and the final grain yield was under-estimated as a result.

\subsubsection{Net carbon exchanges}

The carbon dioxide exchanges measured with micrometeorological systems are usually used to test soil-vegetation-atmosphere transfer (SVAT) models for forest or cropland surface (e.g. De Noblet et al., 2004; Dufrêne et al., 2005; Wang et al., 2005). Here, the originality of our approach was to use these measurements to test the $\mathrm{CO}_{2}$
4, 1059-1092, 2007

\section{Global warming potential of agro-ecosystems}

S. Lehuger et al.

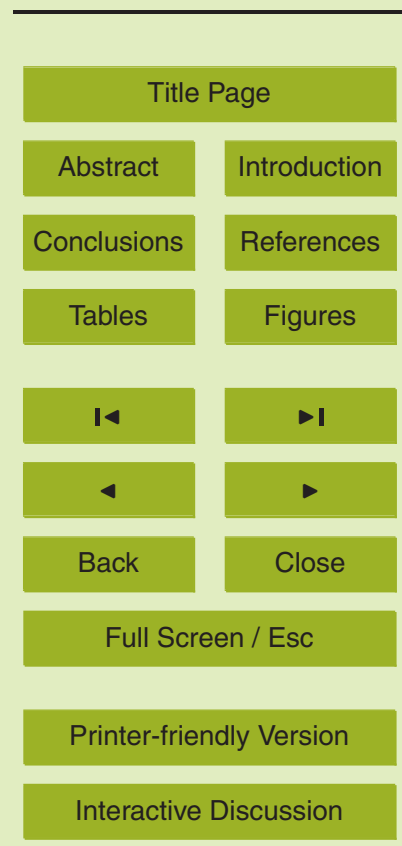

EGU 
EGC to simulate the net $\mathrm{CO}_{2}$ fluxes at the daily time scale. Daily net ecosystem production (NEP) was well predicted (Figs. 1c and d), and was primarily dependent of the net primary production before the soil respiration. The root-mean squared error between model and data NEP values was $1.90 \mathrm{~g} \mathrm{C} \mathrm{m}^{-2} \mathrm{~d}^{-1}$, the mean difference was $5 \quad 0.38 \mathrm{~g} \mathrm{C} \mathrm{m}^{-2} \mathrm{~d}^{-1}$, and the model-data coefficient of determination $\left(R^{2}\right)$ was 0.81 . Adiku et al. (2006) have developed a model (PIXGRO) for simulating the ecosystem $\mathrm{CO}_{2}$ exchange and growth of spring barley by coupling a canopy flux model and crop growth model. Their predictions for $\mathrm{CO}_{2}$ exchanges were more accurate than ours $\left(\mathrm{R}^{2}=0.92\right)$, but they focused their model testing on the gross primary production, without includ10 ing the soil and plant respiration terms as we did. Because both the accumulation of atmospheric $\mathrm{CO}_{2}$ into crop biomass and the net ecosystem exchanges at the soil/plantatmosphere interface were well simulated by the CERES-EGC model, we may hypothesise that the carbon dynamics were correctly predicted over the entire maize growing cycle. Based on this result, we further assumed in the following that CERES-EGC could be extrapolated to calculate the net $C$ exchanges over an entire crop rotation.

\subsubsection{Nitrous oxide emissions}

Figure 3 provides a test for the simulation of the key drivers of $\mathrm{N}_{2} \mathrm{O}$ emissions at the Grignon site. Soil moisture, temperature and inorganic $\mathrm{N}$ content control $\mathrm{N}_{2} \mathrm{O}$ emissions by their influence on the nitrification and denitrification processes. At Grignon, 20 for the period of measurement (13 May to 12 June 2005), their dynamics were well simulated (Figs. 3a, b, c), except for the nitrate content which was not as much removed by the crop uptake at the end of the crop cycle as it was measured (Fig. 3c). However, the model simulated two peak fluxes of $\mathrm{N}_{2} \mathrm{O}$ that were not observed in the field (Fig. 3d). The comparison between simulated and observed data, reported in Table 2, shows, on 25 the one hand, a good performance of the model to simulate the controls of the nitrification and denitrification processes, but also, a large lack of fit in the prediction of $\mathrm{N}_{2} \mathrm{O}$ emissions (RMSE $=20.51 \mathrm{~g} \mathrm{Nha}^{-1} \mathrm{~d}^{-1}, \mathrm{MD}=-6.09 \mathrm{~g} \mathrm{~N} \mathrm{ha}^{-1} \mathrm{~d}^{-1}, \mathrm{R}^{2}=0.004, \mathrm{n}=31$ ).

The first peak flux of $\mathrm{N}_{2} \mathrm{O}$ occurred four days after the application of fertilizer $\mathrm{N}$, in 1070

\section{BGD}

4, 1059-1092, 2007

\section{Global warming potential of agro-ecosystems}

S. Lehuger et al.

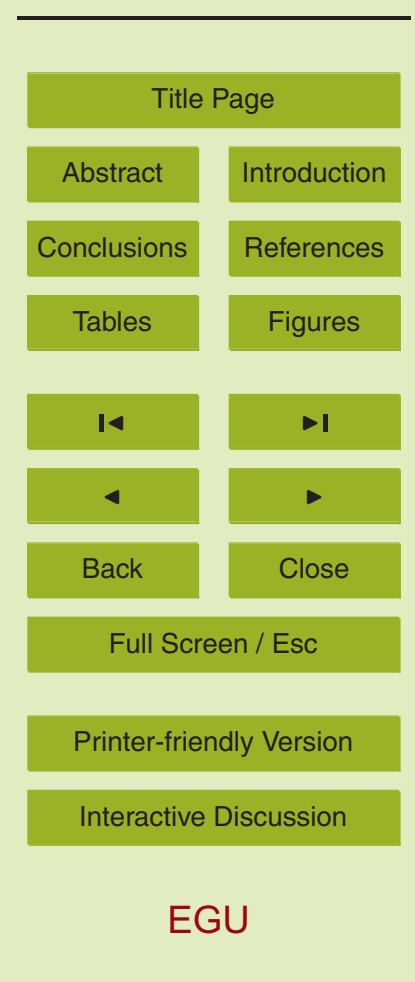


response to rainfall and high soil $\mathrm{N}$ content $\left(\sim 180 \mathrm{~kg} \mathrm{Nha}^{-1}\right)$ in the $0-30 \mathrm{~cm}$ topsoil layer. The model anticipated this peak by 3 days compared to the observations. This may be explained by a possible time lag between the production of gaseous $\mathrm{N}_{2} \mathrm{O}$ in the soil and its emission to the soil surface via a gas diffusion process in the soil which is 5 not accounted for by the model.

Two additional peak fluxes were simulated by the model on days of year (DOY) 149 and 156-157, as a consequence of rainfall and high nitrate content in soil. Despite these a priori conducive conditions for $\mathrm{N}_{2} \mathrm{O}$ emissions, only very small peaks were observed in the field. Therefore, we may hypothesize that for the Grignon' soil the 10 first peak of $\mathrm{N}_{2} \mathrm{O}$ emissions might have been produced in response to the high ammonium content in topsoil $\left(110 \mathrm{~kg} \mathrm{~N}-\mathrm{NH}_{4} \mathrm{ha}^{-1}\right.$ in $0-30 \mathrm{~cm}$ ) rather than high nitrate content $\left(70 \mathrm{~kg} \mathrm{~N}-\mathrm{NO}_{3} \mathrm{ha}^{-1}\right.$ in $\left.0-30 \mathrm{~cm}\right)$. The absence of $\mathrm{N}_{2} \mathrm{O}$ peaks on DOY 149 and 156-157 further supports this hypothesis because in this time period, topsoil ammonium had

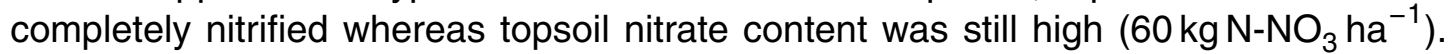
15 There was in addition a good correlation between the measured $\mathrm{N}_{2} \mathrm{O}$ fluxes and soil $\mathrm{NH}_{4}^{+}$content. For the Grignon soil, this could mean that nitrifier denitrification could be an important pathway of $\mathrm{N}_{2} \mathrm{O}$ production and emission. This is further supported by the fact that during this time period the water-filled pore space (WFPS) predicted by the model was greater than $62 \%$ - the threshold that triggers denitrification in the model (Hénault et al., 2000; see Fig. 4). Further investigations in the field and in the laboratory are required to validate this hypothesis.

As a consequence of the discrepancies between the predicted and observed emission pulses, the modelled $\mathrm{N}_{2} \mathrm{O}$ emissions totaled $338 \mathrm{~g} \mathrm{~N}^{-\mathrm{N}_{2}} \mathrm{O}^{-1}$ over the entire measurement period (from DOY 133 to 163), whereas the observed ones totaled $145 \pm 104{\mathrm{~g} \mathrm{~N}-\mathrm{N}_{2}} \mathrm{O} \mathrm{ha}^{-1}$ which implies an overestimation of $133 \%$ by the model.

Other studies with similar modeling approaches mention that the discrepancies between modelled and observed $\mathrm{N}_{2} \mathrm{O}$ data were in the same range of errors than our simulations. For example, Babu et al. (2006) indicate that the DNDC model predicted daily $\mathrm{N}_{2} \mathrm{O}$ fluxes with a large lack of fit $\left(\mathrm{RMSE}=529.6 \mathrm{~g} \mathrm{~N} \mathrm{ha}^{-1}\right.$ day $\left.^{-1}, \mathrm{n}=134\right)$ for rice-based

BGD

4, 1059-1092, 2007

\section{Global warming potential of agro-ecosystems}

S. Lehuger et al.

Title Page

Abstract Introduction

Conclusions

Tables

References

Figures

14

4

Back

Close

Full Screen / Esc

Printer-friendly Version

Interactive Discussion 
production systems in India. In the same way, Del Grosso et al. (2005) showed that the DAYCENT model gave daily prediction of $\mathrm{N}_{2} \mathrm{O}$ emissions with a quite high discrepancy (RMSE $=64 \%, R^{2}=0.74, n=21$ ) for major crops in the USA. Frolking et al. (1998) and $\mathrm{Li}$ et al. (2005) have compared different models or sub-models for their aptitude to sim5 ulate $\mathrm{N}_{2} \mathrm{O}$ emissions from cropland, and in most cases, the models were not able to capture the daily $\mathrm{N}_{2} \mathrm{O}$ flux patterns because of temporal deviation of the fluxes, time lag between observed and modelled peaks and over- or underestimation of the measured peak fluxes.

At Rafidin, $\mathrm{N}_{2} \mathrm{O}$ emissions were very low even for the high- $\mathrm{N}$ input treatment (N2). 10 In fact, for this treatment, the highest emission rate measured was $7.4 \mathrm{~g} \mathrm{Nha}^{-1} \mathrm{~d}^{-1}$, which is four times lower than the highest $\mathrm{N}_{2} \mathrm{O}$ emission rate recorded at the Grignon site. The microbiological parameters of the Rafidin soil for denitrification-mediated $\mathrm{N}_{2} \mathrm{O}$ emission were very low in comparison to other soils previously analyzed (Garrido et al., 2002; Hénault et al., 2005). The potential denitrification rate (PDR) was only $151 \mathrm{~kg} \mathrm{Nha}^{-1} \mathrm{~d}^{-1}$, and the fraction of denitrified nitrate evolved as $\mathrm{N}_{2} \mathrm{O}$ was equal to $9 \%$. In the literature, this potential was reported to vary between 2.5 and $9.5 \mathrm{~kg} \mathrm{~N} \mathrm{ha}^{-1} \mathrm{~d}^{-1}$ for two Gleyic Luvisols, and was around $16 \mathrm{~kg} \mathrm{~N} \mathrm{ha}^{-1} \mathrm{~d}^{-1}$ for Haplic Calcisol and Haplic Luvisol. In addition, the fraction of denitrified nitrate evolved as $\mathrm{N}_{2} \mathrm{O}$ is generally above $20 \%$ (Hénault et al., 2005). In our case, this means that the rates of $\mathrm{N}_{2} \mathrm{O}$ emissions 20 from denitrification were quasi nil. Hénault et al. (2005) estimated that $98 \%$ of the $\mathrm{N}_{2} \mathrm{O}$ emissions originated from the nitrification process at the same Rafidin site. In addition, the same authors showed that a high proportion (84\%) of nitrification-mediated $\mathrm{N}_{2} \mathrm{O}$ was subsequently reduced to $\mathrm{N}_{2}$ through denitrification, when the two processes were concurrent. We accordingly reduced the proportion of total nitrification evolved as $\mathrm{N}_{2} \mathrm{O}$, 25 which resulted in a better fit between simulated and observed $\mathrm{N}_{2} \mathrm{O}$ fluxes. For the three fertilizer $\mathrm{N}$ treatments, the key drivers of $\mathrm{N}_{2} \mathrm{O}$ emissions were correctly simulated (see Table 2 and Fig. 5 for the $\mathrm{N} 1$ treatment), and the predicted rates of $\mathrm{N}_{2} \mathrm{O}$ emissions were satisfactory, with RMSEs of $0.31,1.29$ and $2.16 \mathrm{~g} \mathrm{Nha}^{-1} \mathrm{~d}^{-1}$ for the N0, N1 and $\mathrm{N} 2$ treatments, respectively (see Table 2 ).

\section{BGD}

4, 1059-1092, 2007

\section{Global warming potential of agro-ecosystems}

S. Lehuger et al.

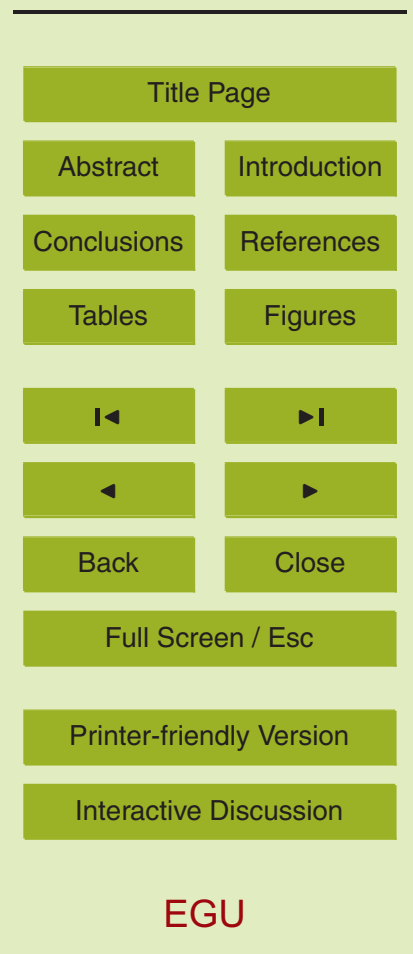


In the previous section, we tested the CERES-EGC model against datasets from two intensive experiments involving different sets of crop types, pedoclimatic conditions, and agricultural practices. The present section deals with the extrapolation of the model 5 to calculate the GWP of complete cropping systems, including soil $\mathrm{C}$ balance and direct emissions of $\mathrm{N}_{2} \mathrm{O}$ in the field. The third term of the GHG balance, namely the indirect emissions, was also added.

The different crops occurring within a given rotation are inter-related in terms of pest management, nutrients' turn-over, and soil organic and mineral status. In addition, the nutrients derived from fertilizers or biological fixation may be recycled or stored into the pools of the SOM, and may be re-emitted into air or water in subsequent years (Del Grosso et al., 2005). That is the reason why it is not relevant to calculate the GWP of a single crop, but rather of a complete sequence of crops. The GWP of this rotation may subsequently be re-allocated to a particular crop based on its frequency of occurrence 15 in the rotation, or similar rules.

\subsubsection{Net ecosystem production and soil organic carbon dynamic}

The carbon dioxide exchanges for a crop growing cycle were assumed to start upon harvest of the preceding crop, and to stop upon harvest of the crop considered. The values of the Fig. 6 were obtained carrying by averaging the fluxes simulated over 10 maize-wheat-barley rotations on a 33-yr series of historical weather data (19722005), with constant crop management. The 30-yr simulation allowed us to explore the climatic variability and its effect on the net primary production and soil respiration. The net production was highest with the maize crop, amounting to $6590 \pm 1460 \mathrm{~kg} \mathrm{Cha}^{-1}$, whereas the NEP of the wheat and barley crops were close to $4000 \mathrm{~kg} \mathrm{Cha}^{-1}$. For the

mustard, the soil respiration term was greater than net photosynthesis, and NEP was $-2000 \mathrm{~kg} \mathrm{C} \mathrm{ha}^{-1}$. Inter-annual variability was quite large for the net primary production, showing a strong dependence of the climate on crop growth. The year-round NEP

\section{BGD}

4, 1059-1092, 2007

\section{Global warming potential of agro-ecosystems}

S. Lehuger et al.

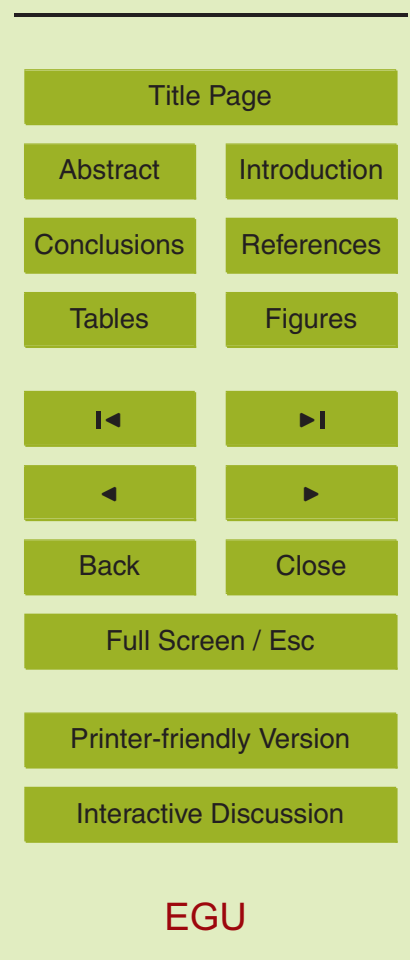


for the year 2005 (encompassing the maize cropping cycle) was $4100 \mathrm{~kg} \mathrm{Cha}^{-1} \mathrm{yr}^{-1}$, which is in accordance with Verma et al. (2005) who measured NEP values for irrigated and rainfed maize crops in Nebraska (USA) between 3800 and $5200 \mathrm{~kg} \mathrm{Cha}^{-1} \mathrm{yr}^{-1}$.

The net stock of $C$ produced by the ecosystem was broken down into harvest prod5 ucts (grain and straw; see Table 3), which were removed from the system, and crop residues (roots, stubble, maize stalks), which were returned to the agro-ecosystem and underwent gradual decomposition by soil microflora.

The variation of SOC storage reflects the difference between net $\mathrm{C}$ uptake by plants, manure inputs, and losses from harvested plant products, crop residues decompo10 sition and SOC mineralization. Over 30-yr simulation period with the maize-wheatbarley rotation in Grignon, we estimated a C sequestration of $135 \mathrm{~kg} \mathrm{Cha}^{-1} \mathrm{yr}^{-1}$ in the topsoil layer (see Fig. 7a), mainly due to the $C$ inputs by the catch crops and crop residues. This value is in accordance with Arrouays et al. (2002), who indicate that the introduction of a catch crop in the rotation may induce a $C$ sequestration of $15160 \pm 80 \mathrm{~kg} \mathrm{Cha}^{-1} \mathrm{yr}^{-1}$. In Grignon, the straw of wheat and barley was removed for use as litter for animal production, whereas in Rafidin the straw was left on the soil surface at harvest, and subsequently incorporated into the topsoil layer. As a consequence, the $\mathrm{C}$ inputs from crop residues were much higher in Rafidin than in Grignon, averaging $4250 \mathrm{~kg} \mathrm{Cha}^{-1} \mathrm{yr}^{-1}$ for the $\mathrm{N} 1$ rotation and $4290 \mathrm{~kg} \mathrm{Cha}^{-1} \mathrm{yr}^{-1}$ for the N2 rotation. With 20 these levels of $C$ inputs to the soil, the CERES-EGC model predicted a $C$ sequestration of $730 \mathrm{~kg} \mathrm{Cha}^{-1} \mathrm{yr}^{-1}$ for the N1-rotation and $750 \mathrm{~kg} \mathrm{Cha}^{-1} \mathrm{yr}^{-1}$ for the N2-rotation, suggesting that the Rafidin soil was a potentially large sink for atmospheric $\mathrm{CO}_{2}$.

To cross-check the above estimate, we used a simplified, one-compartment SOC model based on a C Input-Output balance (Hénin and Dupuis, 1945). Annual inputs to 25 SOC are calculated as a fixed proportion of residue inputs using a humification rate, and $\mathrm{C}$ mineralization losses are proportional to total SOC. The parameters were set according to previous work on rendzina soils of the area (Ballif et al., 1995; Trinsoutrot et al., 2000). The model also predicted a high C storage of $580 \mathrm{~kg} \mathrm{C} \mathrm{ha}^{-1} \mathrm{yr}^{-1}$ for the N2 treatment, which was however $20 \%$ lower than the CERES-EGC estimate. This stems

BGD

4, 1059-1092, 2007

\section{Global warming potential of agro-ecosystems}

S. Lehuger et al.

Title Page

Abstract Introduction

Conclusions

Tables

References

Figures

14

4

Back

Close

Full Screen / Esc

Printer-friendly Version

Interactive Discussion 
from the relatively low SOC mineralization rate of rendzina soils $\left(<0.5 \%\right.$ of SOC $\left.\mathrm{yr}^{-1}\right)$, due to physical protection process by the formation of calcite formation on the organic fractions. Thus, the high level of biomass production permitted by ample fertilizer inputs and the low SOC mineralization rate of the rendzina soil induced a large potential of $\mathrm{C}$ 5 storage, and accordingly a net fixation of atmospheric $\mathrm{CO}_{2}$.

\subsubsection{Indirect emissions}

The GHG cost of agricultural inputs contributes a large part of the GWP of agroecosystems. For the Grignon cropping system, the mean indirect emissions were $360 \mathrm{~kg} \mathrm{CO}_{2}-\mathrm{Ceq} \mathrm{ha}^{-1} \mathrm{yr}^{-1}$, and for the Rafidin system, the mean IE were 410 and tion of these inputs - particularly $\mathrm{N}$ fertilizer production is the top contributor to the IE by a wide margin, with a $55-65 \%$ share (Fig. 8). Cropping operations came next, with a $30-40 \%$ in the total IE term, mainly due to from fossil-fuel combustion by farm machinery. The transport of inputs from the production plant to the farm was the lowest contributor to the GWP with less than $1 \%$ of IE.

\subsection{Global Warming Potential}

The 30-yr simulation period enabled us to explore the effect of climate variability on biomass production and $\mathrm{N}_{2} \mathrm{O}$ emissions. At Grignon, $\mathrm{N}_{2} \mathrm{O}$ emissions averaged $110 \pm 40 \mathrm{~kg} \mathrm{CO}_{2}-\mathrm{C} \mathrm{eq} \mathrm{ha}^{-1} \mathrm{yr}^{-1}$ (CV=36\%) over the maize growing cycle, and we finally 20 estimated a GWP of $350 \pm 35 \mathrm{~kg} \mathrm{CO}_{2}-\mathrm{C} \mathrm{eq} \mathrm{ha}^{-1} \mathrm{yr}^{-1}$ (Table 3 ) for this system. This value is closed to that of $310 \mathrm{~kg} \mathrm{CO}_{2}-\mathrm{C} \mathrm{eq} \mathrm{ha}^{-1} \mathrm{yr}^{-1}$, measured by Robertson et al. (2000) for a conventional maize-soybean-wheat system in the Midwest United States, although its breakdown was quite different. The latter authors found no measurable soil $\mathrm{C}$ sequestration with conventional tillage, whereas we found a significant storage. Also, the system boundaries they set for the indirect emissions were narrower than ours. They only accounted for the $\mathrm{CO}_{2}$ emissions occurring during the production of agricultural

BGD

4, 1059-1092, 2007

\section{Global warming potential of agro-ecosystems}

S. Lehuger et al.

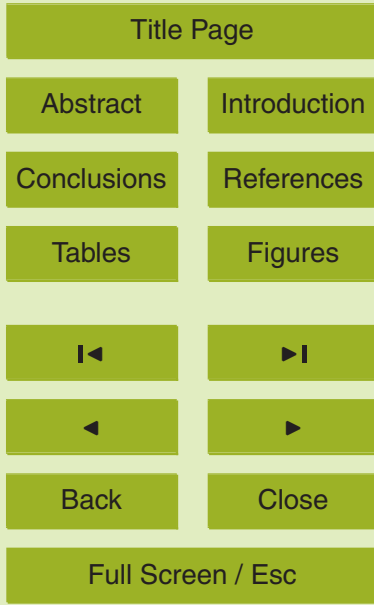

Printer-friendly Version

Interactive Discussion 
inputs, and not the other $\mathrm{GHG}\left(\mathrm{CH}_{4}\right.$ and $\left.\mathrm{N}_{2} \mathrm{O}\right)$, although these may account for half of the total indirect emissions of GHG. Consequently, we estimated a twice higher IE term, which was compensated for by a positive SOC storage in the final balance.

At Rafidin, we estimated very low $\mathrm{N}_{2} \mathrm{O}$ emissions $\left(<40 \mathrm{~kg} \mathrm{CO}_{2}-\mathrm{C}\right.$ eq ha $\left.{ }^{1} \mathrm{yr}^{1}\right)$, and

5 a large $\mathrm{C}$ storage potential resulting from the high level of residue return. The more than offset the emissions of $\mathrm{N}_{2} \mathrm{O}$ and the indirect emissions, so that the GWP was $-290 \pm 10 \mathrm{~kg} \mathrm{CO}_{2}-\mathrm{C}_{\text {eq ha }}^{-1} \mathrm{yr}^{-1}$ for the $\mathrm{N} 1$ system and $-250 \pm 10 \mathrm{~kg} \mathrm{CO}_{2}-\mathrm{C}_{\text {eq ha }}{ }^{-1} \mathrm{yr}^{-1}$ for the N2 system (Table 3). The Rafidin crop rotation is an intensive system with a high level of inputs and indirect emissions of GHG as a result, but it is compensated 10 for by the resulting high potential of biomass production and SOC storage. Overall, the Rafidin system emerges a potentially strong sink of GHG.

\section{Conclusions}

The assessment of the direct emissions at the field scale is paramount in an accurate estimation of GHG balances for agricultural systems. Biophysical modelling of the 15 soil-crop-atmosphere system provides a unique capacity to address this issue while taking into account the complex interactions between $\mathrm{C}$ and $\mathrm{N}$ cycling, as influenced by anthropogenic actions. Here, we tested the ability of the CERES-EGC model to simulate the GHG emissions, and showed it achieved satisfactory predictions of $\mathrm{N}_{2} \mathrm{O}$ and $\mathrm{CO}_{2}$ fluxes for two cropping systems representing distinct pedoclimatic conditions and 20 agricultural practices. As a result, their GWP were markedly different: the wheat-maizebarley rotation on a loamy soil was a net source of GHG, with a GWP of $350 \mathrm{~kg} \mathrm{CO}_{2}$ $\mathrm{C}$ eq ha ${ }^{-1} \mathrm{yr}^{-1}$, while the oilseed rape-wheat-barley rotation on a rendzina was a net sink of GHG with a GWP of $-250 \mathrm{~kg} \mathrm{CO}_{2}-\mathrm{Ceq} \mathrm{ha}^{-1} \mathrm{yr}^{-1}$.

The $\mathrm{C}$ dynamics predicted by the model were validated at the daily time scale against 25 micrometeorological measurements of $\mathrm{CO}_{2}$ exchanges in one of the sites, but it will be necessary to supplement this test by further verifying the ability of CERES-EGC to simulate the rate of changes in the long term. Improvements may also be sought for

\section{BGD}

4, 1059-1092, 2007

\section{Global warming potential of agro-ecosystems}

S. Lehuger et al.

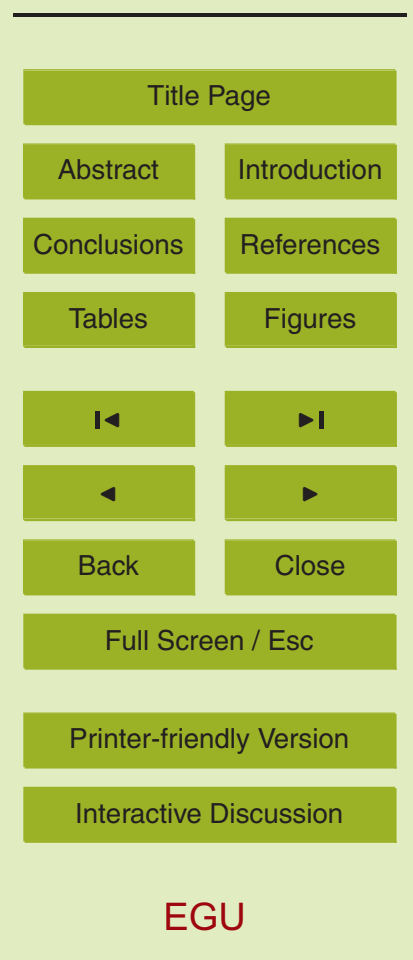


the $\mathrm{N}_{2} \mathrm{O}$ emission sub-model through tests on a wider range of experimental sites and datasets, in order to broaden its validation field and to develop its robustness, or to include new processes (e.g. nitrifier denitrification) in the modeling system. With a sufficiently large sample of experimental datasets, Bayesian methods may be applied 5 to calibrate some of the parameters of this sub-model, and carry out an uncertainty analysis of the simulations (Van Oijen et al., 2005).

The modeling approach presented here could also be used to devise different strategies to mitigate the GWP of cropping systems. Various scenarios involving some modifications of crop management (e.g., fertilization, rotation, crop types) could be tested for

10 this purpose. Other environmental impacts may be output by the model and included in the analysis, in particular the emissions into air or water of $\mathrm{NH}_{3}, \mathrm{NO}_{3}^{-}$, or $\mathrm{NO}$. Thus, the overall environmental balance of the agricultural systems may be approached, making it possible to design agricultural systems with high environmental performance.

Acknowledgements. Financial support from CarboEurope and NitroEurope integrated projects 15 (European Commission Framework VI research programme) is acknowledged. The authors would like to thank M. Lauransot and $\mathrm{O}$. Zurfluh for their assistance in the collection and analysis of field data.

\section{References}

Adiku, S. G. K., Reichstein, M., Lohila, A., Dinh, N. Q., Aurela, M., Laurila, T., Lueers, J., and 20 Tenhunen, J. D.: PIXGRO: A model for simulating the ecosystem $\mathrm{CO}_{2}$ exchange and growth of spring barley, Ecol. Modell., 190, 260-276, 2006.

Arrouays, D., Balesdent, J., Germon, J. C., Jayet, P. A., Soussana, J. F., and Stengel, P.: Stocker du carbone dans les sols agricoles de France?, Expertise Scientifique Collective., INRA, Paris, 330, 2002.

25 Babu, Y. J., Li, C., Frolking, S., Nayak, D. R., and Adhya, T. K.: Field validation of DNDC model for methane and nitrous oxide emissions from rice-based production systems of india, Nutr. Cycl. Agroecosyst., 74, 157-174, 2006.

BGD

4, 1059-1092, 2007

\section{Global warming potential of agro-ecosystems}

S. Lehuger et al.

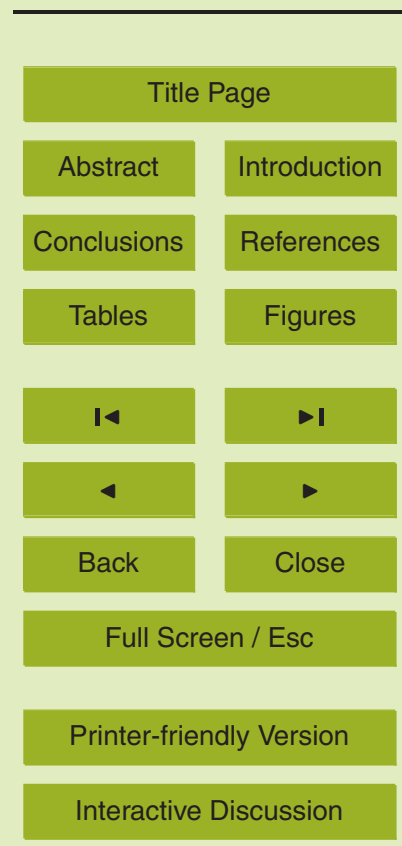

EGU 
Ballif, J. L., Guérin, H., and Muller, J. C.: Eléments d'agronomie champenoise. Connaissance des sols et de leur fonctionnement. Rendzines sur craie et sols associés, INRA, Paris, 92, 1995.

Bhatia, A., Pathak, H., Jain, N., Singh, P. K., and Singh, A. K.: Global warming potential of manure amended soils under rice-wheat system in the Indo-Gangetic plains, Atmos. Environ., 39, 6976-6984, 2005.

Boote, K. J., Jones, J. W., and Pickering, N. B.: Potential uses and limitations of crop models, Agronomy J., 88, 704-716, 1996.

Del Grosso, S. J., Mosier, A. R., Parton, W. J., and Ojima, D. S.: DAYCENT model analysis of past and contemporary soil $\mathrm{N}_{2} \mathrm{O}$ and net greenhouse gas flux for major crops in the USA, Soil Tillage Res., 83, 9-24, 2005.

Desjardins, R. L., Smith, W., Grant, B., Campbell, C., and Riznek, R.: Management strategies to sequester carbon in agricultural soils and to mitigate greenhouse gas emissions, Climatic Change, 70, 283-297, 2005.

Dufrêne, E., Davi, H., Francois, C., le Maire, G., Le Dantec, V., and Granier, A.: Modelling carbon and water cycles in a beech forest Part I: Model description and uncertainty analysis on modelled NEE, Ecol. Modell., 185, 407-436, 2005.

Duxbury, J. M., Harper, L. A., and Mosier, A. R.: Contributions of agro-ecosystems to global climate change in: Agricultural Ecosystem Effects on Trace Gases and Global Climate Change. ASA Special Publication 55. D. E. Rolston, J. M. Duxbury, L. A. Harper and A. R. Mosier (eds.). American Society of Agronomy, Crop Science Society of America and Soil Science Society of America, Madison, USA, 1-18, 1993

Falge, E., Baldocchi, D., Olson, R., et al.: Gap filling strategies for defensible annual sums of net ecosystem exchange, Agric. Forest Meteorol., 107, 43-69, 2001.

Frolking, S. E., Mosier, A. R., Ojima, D. S., Li, C., Parton, W. J., Potter, C. S., Priesack, E., Stenger, R., Haberbosch, C., Dorsch, P., Flessa, H., and Smith, K. A.: Comparison of $\mathrm{N}_{2} \mathrm{O}$ emissions from soils at three temperate agricultural sites: simulations of year-round measurements by four models, Nutr. Cycl. Agroecosyst., 52, 77-105, 1998.

Gabrielle, B., Menasseri, S., and Houot, S.: Analysis and field evaluation of the CERES models water balance component, Soil Sci. Soc. Am. J., 59, 1403-1412, 1995.

Gabrielle, B., Roche, R., Angas, P., Cantero-Martinez, C., Cosentino, L., Mantineo, M., Langensiepen, M., Henault, C., Laville, P., Nicoullaud, B., and Gosse, G.: A priori parameterisation of the CERES soil-crop models and tests against several European data sets, Agronomie,

BGD

4, 1059-1092, 2007

\section{Global warming potential of agro-ecosystems}

S. Lehuger et al.

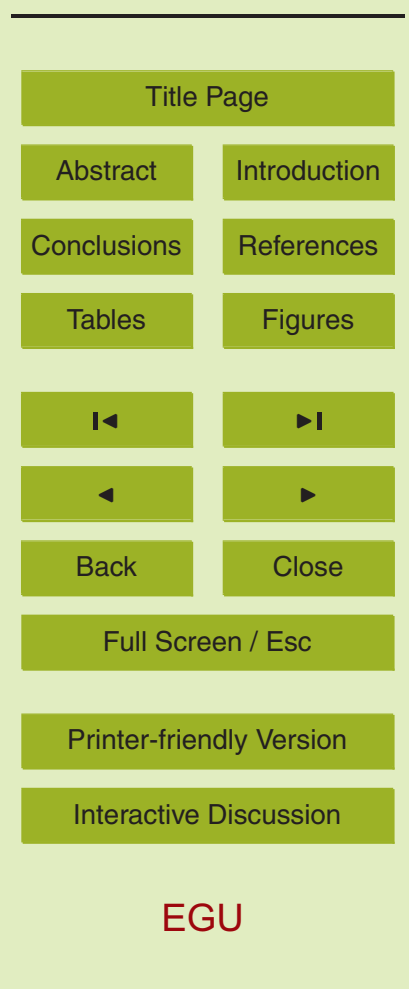


22, 119-132, 2002.

Gabrielle, B., Laville, P., Duval, O., Nicoullaud, B., Germon, J. C., and Henault, C.: Processbased modeling of nitrous oxide emissions from wheat-cropped soils at the subregional scale, Global Biogeochem. Cycles, 20, Art. No. GB4018, 2006.

5 Gabrielle, B. and Gagnaire, N.: Life-cycle assessment of straw use in bio-ethanol production: a case-study based on deterministic modelling, Biomass and Bioenergy, in press, 2007.

Garrido, F., Henault, C., Gaillard, H., Perez, S., and Germon, J. C.: $\mathrm{N}_{2} \mathrm{O}$ and NO emissions by agricultural soils with low hydraulic potentials, Soil Biol. Biochem., 34, 559-575, 2002.

Gijsman, A. J., Hoogenboom, G., Parton, W. J., and Kerridge, P. C.: Modifying DSSAT crop models for low-input agricultural systems using a soil organic matter-residue module from CENTURY, Agronomy J., 94, 462-474, 2002.

Gitz, V. and Ciais, P.: Amplifying effects of land-use change on future atmospheric $\mathrm{CO}_{2}$ levels, Global Biogeochem. Cycles, 17, 2003.

Gosse, G., Cellier, P., Denoroy, P., Gabrielle, B., Laville, P., Leviel, B., Justes, E., Nicolardot,

15 B., Mary, B., Recous, S., Germon, J. C., Henault, C., and Leech, P. K.: Water, carbon and nitrogen cycling in a rendzina soil cropped with winter oilseed rape: the Chalons Oilseed Rape Database, Agronomie, 19, 119-124, 1999.

Hénault, C., Bizouard, F., Laville, P., Gabrielle, B., Nicoullaud, B., Germon, J. C., and Cellier, P.: Predicting in situ soil $\mathrm{N}_{2} \mathrm{O}$ emission using NOE algorithm and soil database, Global Change Biol., 11, 115-127, 2005.

Hénault, C. and Germon, J. C.: NEMIS, a predictive model of denitrification on the field scale, European J. Soil Science, 51, 257-270, 2000.

Hénin, S. and Dupuis, M.: Essai de bilan de matière organique des sols, Ann. Agronomiques, 15, 161-172, 1945.

Hutchinson, G. L. and Davidson, E. A.: Processes for Production and Consumption of Gaseous Nitrogen oxides in Soil, in: Agricultural Ecosystem Effects on Trace Gases and Global Climate Change. ASA Special Publication 55, edited by: Rolston, D. E., Duxbury, J. M., Harper, L. A., and Mosier, A. R., American Society of Agronomy, Crop Science Society of America and Soil Science Society of America, Madison, USA, 79-93, 1993

30

International Panel on Climate Change (IPCC): Climate Change 2001: The scientific basis, Cambridge University Press, Cambridge, 881, 2001.

Jones, C. A. and Kiniry, J. R.: CERES-N Maize: a simulation model of maize growth and development, Texas A\&M University Press, College Station, Temple, TX, 1986.
BGD

4, 1059-1092, 2007

\section{Global warming potential of agro-ecosystems}

S. Lehuger et al.

Title Page

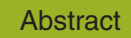

Introduction

Conclusions

References

Tables

Figures

14

-1

4

Back

Close

Full Screen / Esc

Printer-friendly Version

Interactive Discussion 
Jungkunst, H. F., Freibauer, A., Neufeldt, H., and Bareth, G.: Nitrous oxide emissions from agricultural land use in Germany - a synthesis of available annual field data, J. Plant Nutr. Soil Sci., 169, 341-351, 2006.

Kaiser, E. A. and Ruser, R.: Nitrous oxide emissions from arable soils in Germany - An evaluation of six long-term field experiments, J. Plant Nutr. Soil Sci., 163, 249-259, 2000.

Kim, S. and Dale, B. E.: Environmental aspects of ethanol derived from no-tilled corn grain: nonrenewable energy consumption and greenhouse gas emissions, Biomass Bioenergy, 28, 475-489, 2005.

Li, C. S., Frolking, S., and Butterbach-Bahl, K.: Carbon sequestration in arable soils is likely to increase nitrous oxide emissions, offsetting reductions in climate radiative forcing, Climatic Change, 72, 321-338, 2005.

Li, Y., Chen, D. L., Zhang, Y. M., Edis, R., and Ding, H.: Comparison of three modeling approaches for simulating denitrification and nitrous oxide emissions from loam-textured arable soils, Global Biogeochem. Cycles, 19, Art. No. GB3002, 2005.

Molina, J. A. E., Clapp, C. E., Shaffer, M. J., Chichester, F. W., and Larson, W. E.: NCSOIL, a model of nitrogen and carbon transformations in soil: description, calibration, and behavior, Soil Sci. Soc. Am. J., 47, 85-91, 1983.

Mosier, A. R., Duxbury, J. M., Freney, J. R., Heinemeyer, O., Minami, K., and Johnson, D. E.: Mitigating agricultural emissions of methane, Climatic Change, 40, 39-80, 1998.

20 Mosier, A. R., Halvorson, A. D., Peterson, G. A., Robertson, G. P., and Sherrod, L.: Measurement of net global warming potential in three agroecosystems, Nutr. Cycl. Agroecosyst., 72 , 67-76, 2005.

Nemecek, T., Heil, A., Huguenin, O., Erzinger, S., Blaser, S., Dux, D., and Zimmerman, A.: Life Cycle Inventories of Production systems. Final report Ecoinvent 2000 No 15, FAL Reckenholz, FAT Tänikon, Swiss Centre For Life Cycle Inventories, Dübendorf, CH, 284, 2003.

de Noblet-Ducoudré, N., Gervois, S., Ciais, P., Viovy, N., Brisson, N., Seguin, B., and Perrier, A.: Coupling the Soil-Vegetation-Atmosphere-Transfer Scheme ORCHIDEE to the agronomy model STICS to study the influence of croplands on the European carbon and water budgets, Agronomie, 24, 397-407, 2004.

30 Pathak, H., Li, C., and Wassmann, R.: Greenhouse gas emissions from Indian rice fields: calibration and upscaling using the DNDC model, Biogeosciences, 2, 113-123, 2005, http://www.biogeosciences.net/2/113/2005/.

Ritchie, J. T.: Model for predicting evaporation from a row crop with incomplete cover, Water

BGD

4, 1059-1092, 2007

\section{Global warming potential of agro-ecosystems}

S. Lehuger et al.

Title Page

Abstract

Introduction

Conclusions

References

Tables

Figures

14

4

Back

Close

Full Screen / Esc

Printer-friendly Version

Interactive Discussion 
Resources Research, 8, 1204-1213, 1972.

Robertson, G. P., Paul, E. A., and Harwood, R. R.: Greenhouse gases in intensive agriculture: Contributions of individual gases to the radiative forcing of the atmosphere, Science, 289, 1922-1925, 2000.

5 Six, J., Ogle, S. M., Breidt, F. J., Conant, R. T., Mosier, A. R., and Paustian, K.: The potential to mitigate global warming with no-tillage management is only realized when practised in the long term, Global Change Biol., 10, 155-160, 2004.

Smith, J. U., Smith, P., and Addiscott, T. M.: Quantitative methods to evaluate and compare soil organic matter (SOM) models, in: Evaluation of Soil Organic Matter Models, edited by: Powlson, D., Smith, J. U., and Smith, P., Springer-Verlag, Berlin Heidelberg, 181-199, 1996. Smith, P., Goulding, K. W., Smith, K. A., Powlson, D. S., Smith, J. U., Falloon, P., and Coleman, $\mathrm{K}$.: Enhancing the carbon sink in European agricultural soils: including trace gas fluxes in estimates of carbon mitigation potential, Nutr. Cycl. Agroecosyst., 60, 237-252, 2001.

Trinsoutrot, I., Nicolardot, B., Justes, E., and Recous, S.: Decomposition in the field of residues 15 of oilseed rape grown at two levels of nitrogen fertilisation. Effects on the dynamics of soil mineral nitrogen between successive crops, Nutr. Cycl. Agroecosyst., 56, 125-137, 2000.

Van Oijen, M., Rougier, J., and Smith, R.: Bayesian calibration of process-based forest models: bridging the gap between models and data, Tree Physiology, 25, 915-927, 2005.

Verma, S. B., Dobermann, A., Cassman, K. G. et al.: Annual carbon dioxide exchange in irrigated and rainfed maize-based agroecosystems, Agric. Forest Meteorol., 131, 77-96, 2005.

Wang, Q. X., Masataka, W., and Zhu, O. Y.: Simulation of water and carbon fluxes using BIOME-BGC model over crops in China, Agric. Forest Meteorol., 131, 209-224, 2005.

Wrage, N., Velthof, G. L., van Beusichem, M. L., and Oenema, O.: Role of nitrifier denitrification in the production of nitrous oxide, Soil Biol. Biochem., 33, 1723-1732, 2001.

West, T. O. and Marland, G.: Net carbon flux from agricultural ecosystems: methodology for full carbon cycle analyses, Environ. Pollut., 116, 439-444, 2002.

Zhang, Y., Li, C. S., Zhou, X. J., and Moore, B.: A simulation model linking crop growth and soil biogeochemistry for sustainable agriculture, Ecol Modell., 151, 75-108, 2002.
BGD

4, 1059-1092, 2007

\section{Global warming potential of agro-ecosystems}

S. Lehuger et al.

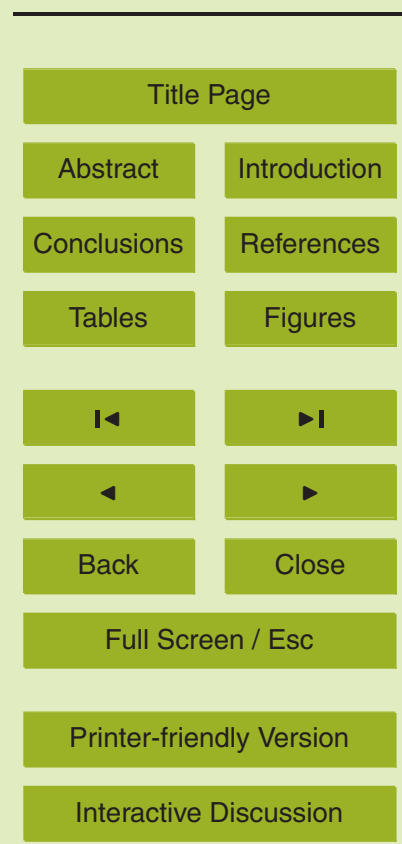

EGU 


\section{BGD}

4, 1059-1092, 2007

Table 1. Experimental treatments and fertilizer $\mathrm{N}$ input rates at the Grignon and Rafidin sites.

\begin{tabular}{ccccc}
\hline & & \multicolumn{3}{c}{ N Fertilizer } \\
\hline Site & Crop & Sowing date & Date & Amount $\left(\mathrm{kg} \mathrm{N} \mathrm{ha}^{1}\right)$ \\
\hline Rafidin & Rapeseed N1 & $09 / 04 / 1994$ & $20 / 02 / 1995$ & 80 \\
& & & $15 / 03 / 1995$ & 75 \\
& Rapeseed N2 & $09 / 04 / 1994$ & $12 / 09 / 1994$ & 49 \\
& & & $20 / 02 / 1995$ & 80 \\
& & & $15 / 03 / 1995$ & 75 \\
Wheat & $27 / 10 / 1995$ & $29 / 03 / 1995$ & 38 \\
& & & $10 / 02 / 1996$ & 60 \\
& & & $10 / 05 / 1996$ & 95 \\
& Barley & $27 / 10 / 1995$ & $10 / 02 / 1997$ & 65 \\
& & & $10 / 03 / 1997$ & 80 \\
& Wheat & $16 / 10 / 2002$ & $26 / 02 / 2003$ & 52 \\
& & & $27 / 03 / 2003$ & 60 \\
& Barley & $17 / 10 / 2003$ & $18 / 02 / 2004$ & 59 \\
& & & $19 / 03 / 2004$ & 59 \\
& & & $02 / 04 / 2004$ & 39 \\
& Mustard & $02 / 09 / 2004$ & $31 / 08 / 2004$ & 90 (Manure) \\
& Maize & $09 / 05 / 2005$ & $09 / 05 / 2005$ & 140 \\
\hline
\end{tabular}

\section{Global warming potential of agro-ecosystems}

S. Lehuger et al.

\section{Title Page}

Abstract

Introduction

Conclusions

References

Tables

Figures

14

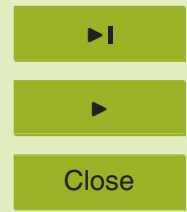

Back

Close

\section{Full Screen / Esc}

Printer-friendly Version 
BGD

4, 1059-1092, 2007

Global warming potential of agro-ecosystems

S. Lehuger et al.

Table 2. Goodness of fit indicators for the simulation of $\mathrm{N}_{2} \mathrm{O}$ drivers by CERES-EGC at Grignon and Rafidin (N1 and N2 treatments).

\begin{tabular}{cccccccc}
\hline & & \multicolumn{2}{c}{ Grignon } & \multicolumn{2}{c}{ Rafidin N1 } & \multicolumn{2}{c}{ Rafidin N2 } \\
\hline & Unit & MD & RMSE & MD & RMSE & MD & RMSE \\
\hline Water content & $\mathrm{v} / \mathrm{v}$ & 0.01 & 0.03 & 0.02 & 0.04 & 0.01 & 0.03 \\
Ammonium content & $\mathrm{kg} \mathrm{NH}_{4}-\mathrm{N} \mathrm{ha}^{-1}$ & 0.57 & 1.97 & 4.43 & 5.6 & 5.01 & 6.72 \\
Nitrate content & $\mathrm{kg} \mathrm{NO}_{3}-\mathrm{N} \mathrm{ha}^{-1}$ & 20.83 & 25.53 & -1.02 & 7.97 & -4.45 & 15.46 \\
$\mathrm{~N}_{2} \mathrm{O}$ emissions & $\mathrm{g} \mathrm{N}_{2} \mathrm{O}-\mathrm{N} \mathrm{ha}^{-1} \mathrm{~d}^{-1}$ & -6.09 & 20.51 & -0.64 & 1.29 & -0.03 & 2.16 \\
\hline
\end{tabular}

Title Page

Abstract

Introduction

Conclusions

References

Tables

Figures

14

$>$ I

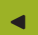

Back

Close

\section{Full Screen / Esc}

Printer-friendly Version

Interactive Discussion 
Table 3. Simulations of the grain yields, straw removal rates, and net global warming potential (GWP) of the Grignon and the Rafidin cropping systems, averaged over 30 years of simulation. The three terms included in the GWP are the variations in soil $C$ storage, the $\mathrm{N}_{2} \mathrm{O}$ emissions and the indirect GHG costs of agricultural inputs.

\begin{tabular}{ccccccc}
\hline & Grain yield & Straw removal & Soil C & N2O & $\begin{array}{c}\text { Agricultural } \\
\text { inputs }\end{array}$ & Net GWP \\
\cline { 2 - 7 } & \multicolumn{2}{c}{$\mathrm{tDM} \mathrm{ha}^{-1}$} & & $\mathrm{~kg} \mathrm{CO} 2-\mathrm{C} \mathrm{eq} \mathrm{ha}^{-1} \mathrm{y}^{-1}$ & \\
\hline GRIGNON & & & & & & \\
Maize & 9.3 & 0 & -102 & $108(39)$ & 330 & $336(39)$ \\
Wheat & 10.2 & 4.2 & -102 & $49(18)$ & 289 & $236(18)$ \\
Barley & 8.3 & 4.1 & -102 & $154(45)$ & 417 & $469(45)$ \\
Mustard & 0 & 0 & -102 & $89(21)$ & 35 & $22(21)$ \\
Rotation & & & -136 & $133(34)$ & 357 & $354(36)$ \\
& & & & & & \\
RAFIDIN & & & & & & \\
Rape N1 & 4.3 & 0 & -732 & $35(9)$ & 359 & $-338(9)$ \\
Wheat & 7.3 & 0 & -732 & $40(6)$ & 470 & $-222(6)$ \\
Barley & 7.1 & 0 & -732 & $33(6)$ & 397 & $-302(6)$ \\
Rotation N1 & & & -732 & $36(7)$ & 409 & $-287(7)$ \\
Rape N2 & 4.8 & 0 & -750 & $44(10)$ & 506 & $-199(10)$ \\
Wheat & 7.3 & 0 & -750 & $41(7)$ & 470 & $-239(7)$ \\
Barley & 7.1 & 0 & -750 & $34(7)$ & 397 & $-319(7)$ \\
Rotation N2 & & & -750 & $40(8)$ & 460 & $-253(8)$ \\
\hline
\end{tabular}

BGD

4, 1059-1092, 2007

Global warming potential of agro-ecosystems

S. Lehuger et al.

Title Page

Abstract

Introduction

Conclusions

References

Tables

Figures

14

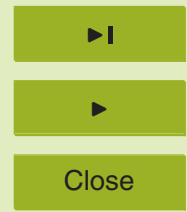

Back

Close

\section{Full Screen / Esc}

Printer-friendly Version

Interactive Discussion 
a)

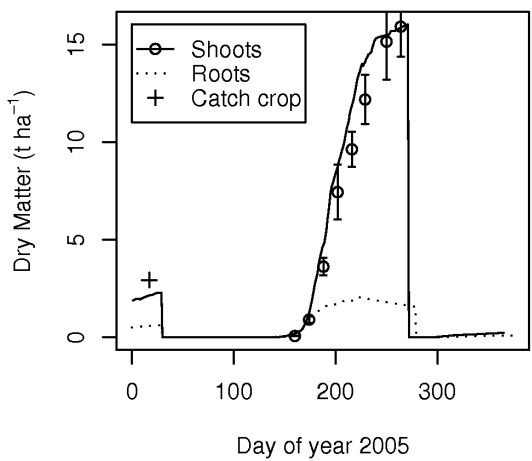

c)

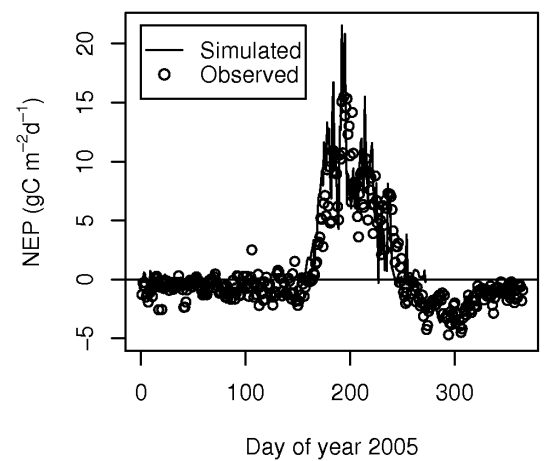

b)

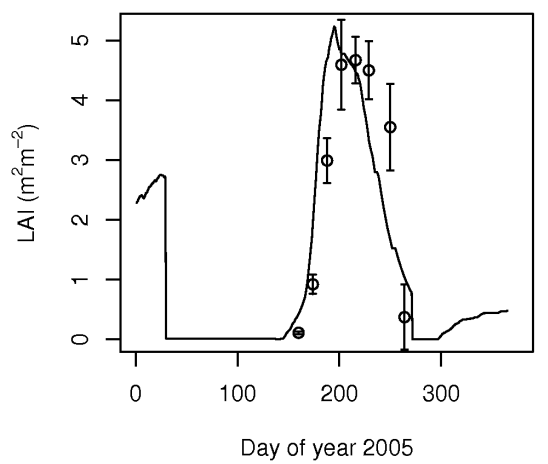

d)

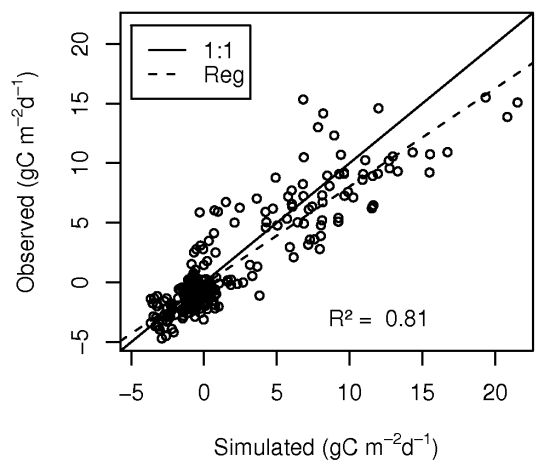

BGD

4, 1059-1092, 2007

Global warming potential of agro-ecosystems

S. Lehuger et al.

\section{Title Page}

\section{Abstract}

Introduction

Conclusions

References

Tables

Figures

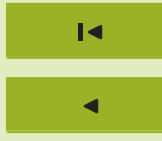

I

Back

Close

\section{Full Screen / Esc}

Printer-friendly Version

Fig. 1. Simulated (lines) and measured (symbols, \pm sd) data for (a) shoots, roots and aerial catch crop dry matter; (b) Leaf Area Index (LAI); (c) net ecosystem production (NEP) and (d) comparison between simulated and observed NEP for the experiments on the maize crop at Grignon in 2005 (France). 
a) N1 treatment

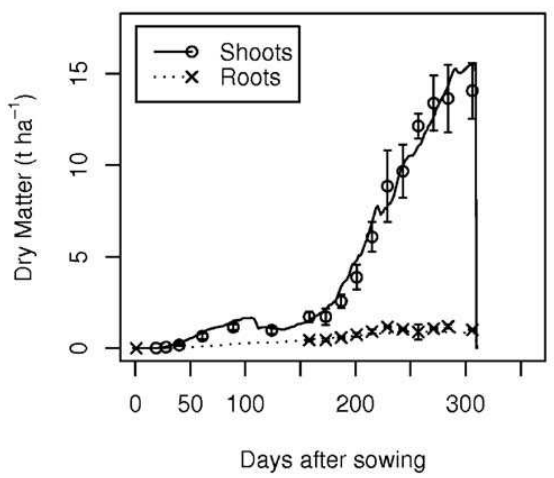

c) N2 treatment

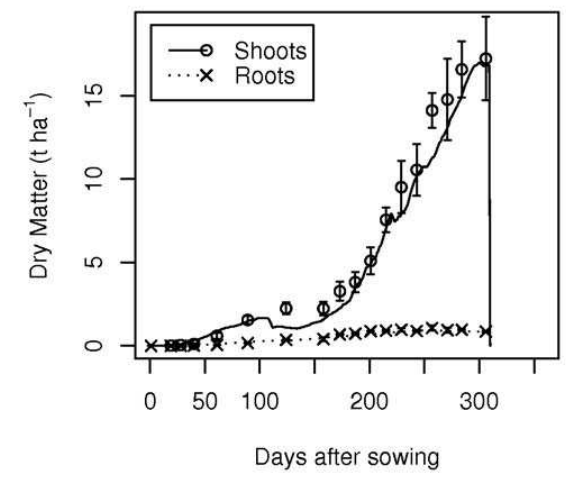

b) N1 treatment

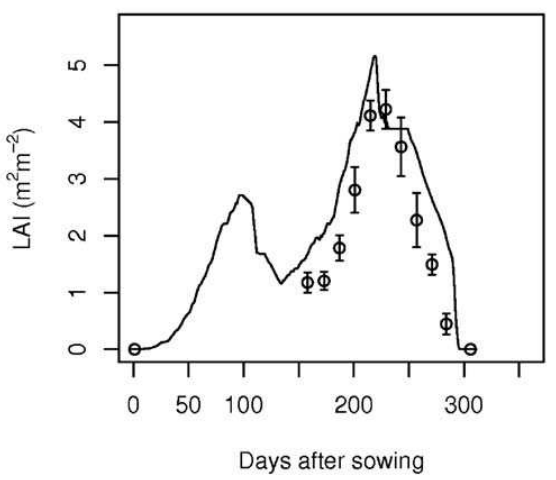

d) N2 treatment

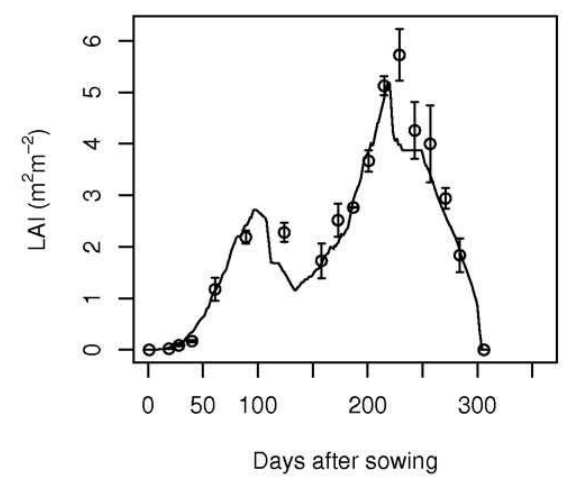

BGD

4, 1059-1092, 2007

\section{Global warming} potential of agro-ecosystems

S. Lehuger et al.

Title Page
Abstract

Conclusions

Tables

14

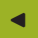

Back
Introduction

References

Figures

$\rightarrow$

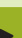

Close

\section{Full Screen / Esc}

Printer-friendly Version

Interactive Discussion

Fig. 2. Simulated (lines) and measured (symbols, \pm sd) data for (a) shoots and roots dry matter for N1 treatment; (b) Leaf Area Index (LAI) for N1 treatment; (c) shoots and roots dry matter for N2 treatment and (d) Leaf Area Index (LAl) for N2 treatment, in 1995 at Rafidin (France). 
a)

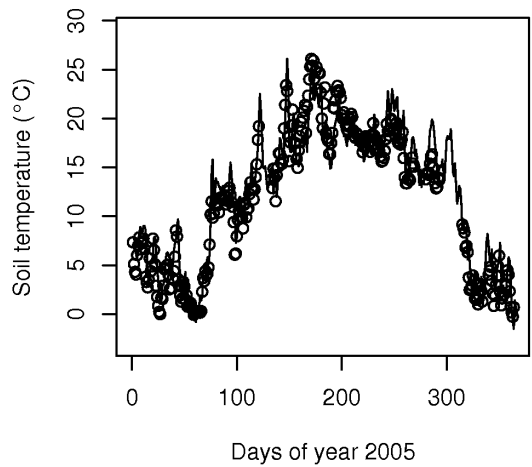

c)

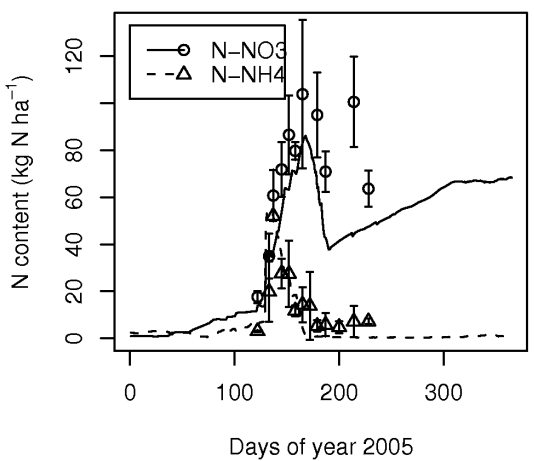

b)

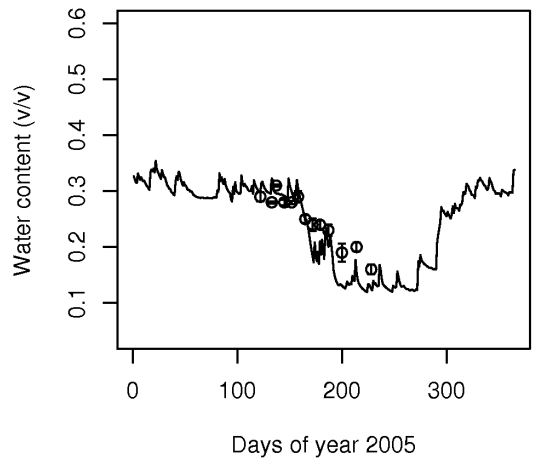

d)

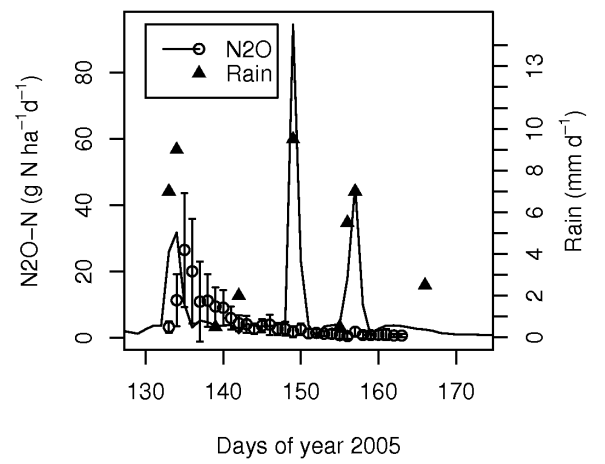

BGD

4, 1059-1092, 2007

Global warming potential of agro-ecosystems

S. Lehuger et al.

Title Page

Abstract

Introduction

Conclusions

References

Tables

Figures

14

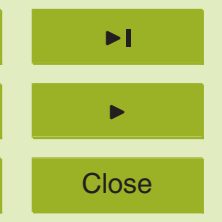

Back

Close

\section{Full Screen / Esc}

Printer-friendly Version

Fig. 3. Simulated (lines) and measured (symbols, $\pm s d$, when available) topsoil $(0-30 \mathrm{~cm})$ data for (a) soil temperature; (b) soil water content; (c) soil $\mathrm{NO}_{3}-\mathrm{N}$ and $\mathrm{NH}_{4}-\mathrm{N}$ contents and (d) $\mathrm{N}_{2} \mathrm{O}$ emissions and rainfall for the maize experiments at Grignon. The error bars for the $\mathrm{N}_{2} \mathrm{O}$ observations correspond to the variability (sd) between the three chambers of measurement. 
BGD

4, 1059-1092, 2007

\section{Global warming potential of agro-ecosystems}

S. Lehuger et al.

Title Page

Abstract

Introduction

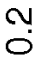
0

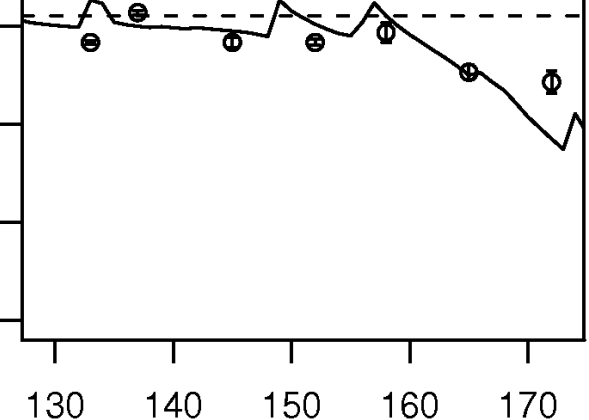

Days of year 2005

Fig. 4. Simulated (line) and observed (symbols, $\pm($ sd) water-filled pore space (WFPS), and 0.62 threshold for the WFPS function in the $\mathrm{N}_{2} \mathrm{O}$ sub-model (dashed line; Grignon, 2005).
References

Conclusions

Tables

Figures

14

4

Back

Close

Full Screen / Esc

Printer-friendly Version

Interactive Discussion 
a)

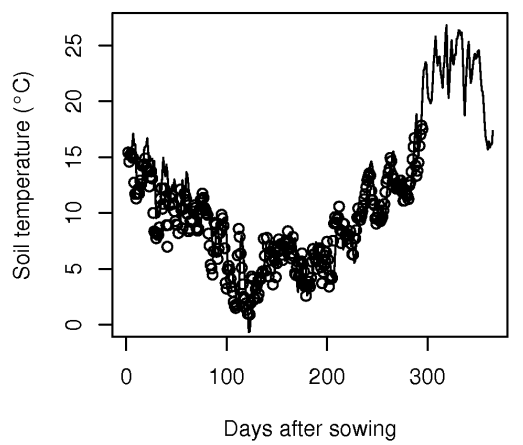

c)

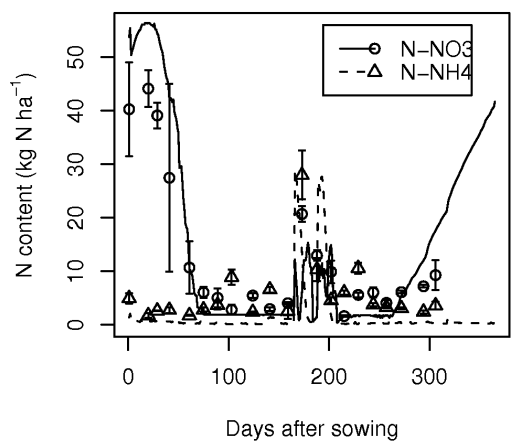

b)

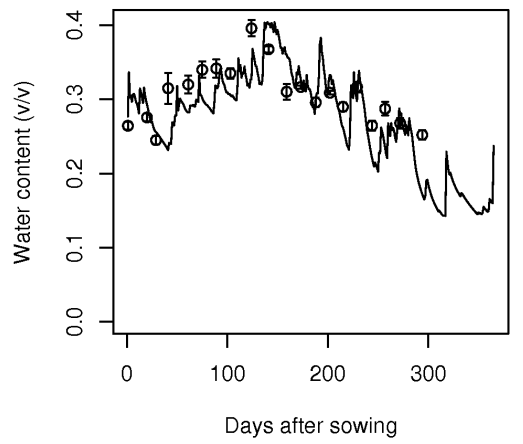

d)

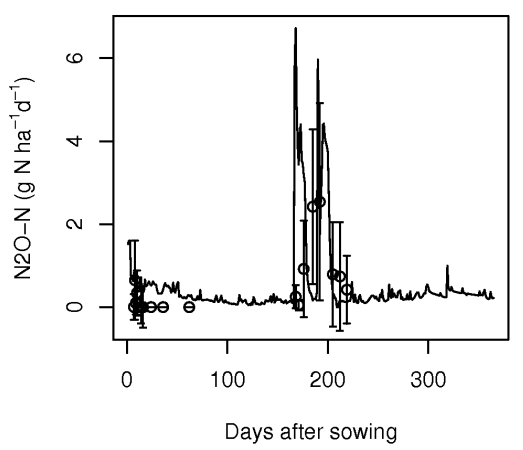

BGD

4, 1059-1092, 2007

Global warming potential of agro-ecosystems

S. Lehuger et al.

\section{Title Page}

Abstract

Introduction

Conclusions

References

Tables

Figures

14

4

Back

\section{Full Screen / Esc}

Printer-friendly Version

Interactive Discussion

Fig. 5. Simulated (lines) and measured (symbols, \pm sd when available) topsoil $(0-30 \mathrm{~cm})$ data for (a) soil temperature; (b) soil water content; (c) soil $\mathrm{NO}_{3}-\mathrm{N}$ and $\mathrm{NH}_{4}-\mathrm{N}$ contents and (d) $\mathrm{N}_{2} \mathrm{O}$ emissions for the rapeseed $\mathrm{N} 1$ experiment at Rafidin. The error bars for the $\mathrm{N}_{2} \mathrm{O}$ observations correspond to the variability (sd) between the 8 measurement replicates. 
BGD

4, 1059-1092, 2007

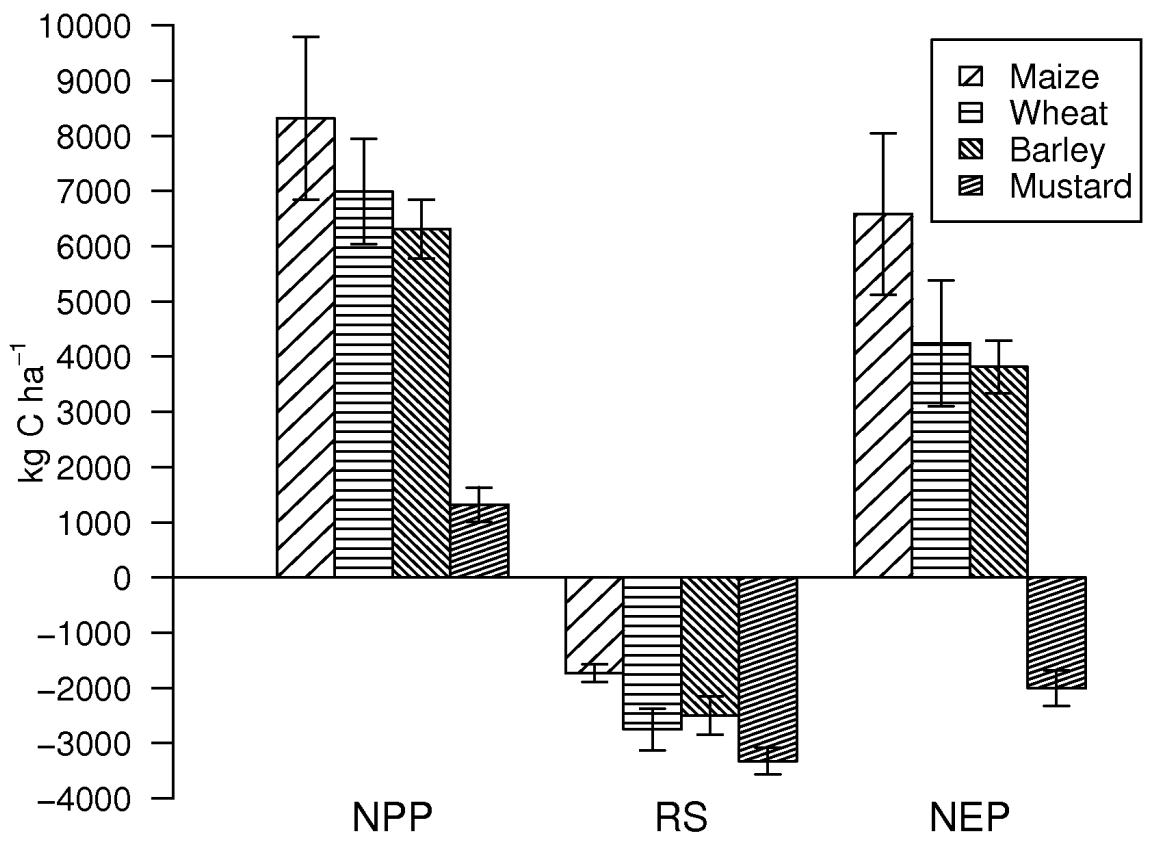

\section{Global warming potential of agro-ecosystems}

S. Lehuger et al.

Title Page

Abstract

Introduction

Conclusions

References

Tables

Figures

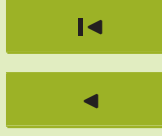

Back

Close

\section{Full Screen / Esc}

Fig. 6. Breakdown of net ecosystem production (NEP) into net primary production (NPP) and soil respiration (Rs) for the four crops of the rotation (Maize, Wheat, Barley and Mustard) at the Grignon site.

Printer-friendly Version

Interactive Discussion 
BGD

4, 1059-1092, 2007

\section{Global warming potential of agro-ecosystems}

S. Lehuger et al.
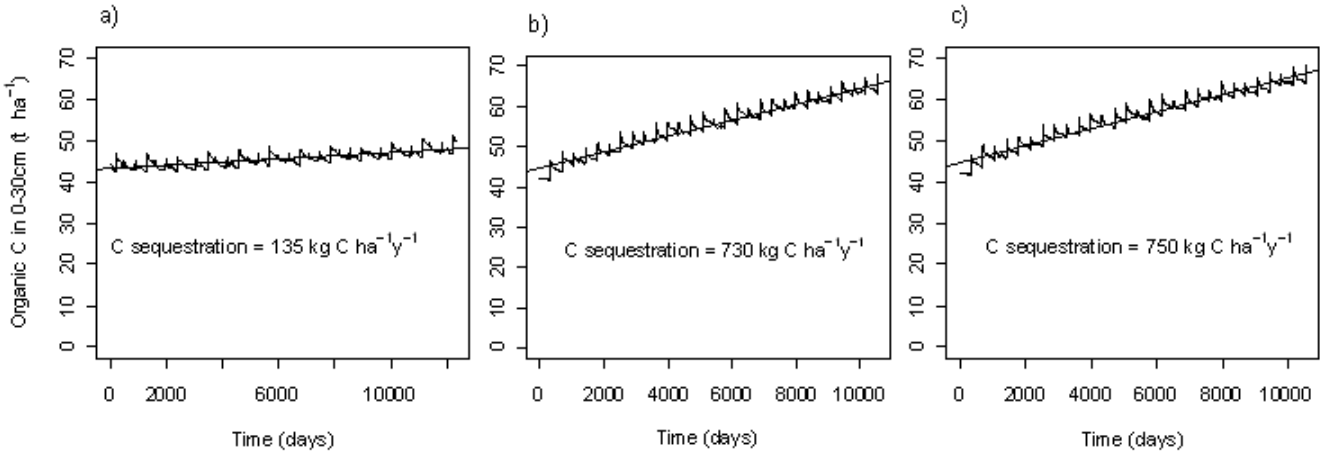

Fig. 7. Simulated changes of $C$ stock $\left(\mathrm{t} \mathrm{Cha}^{-1}\right)$ in the topsoil $(0-30 \mathrm{~cm})$, from 1972 to 2005 , for the Maize-Wheat-Barley-Mustard rotation in Grignon (a), and from 1973 to 2002 for the N1 Rapeseed-Wheat-Barley (b) and the N2-Wheat-Barley rotations in Rafidin (c).

\section{Title Page}

Abstract Introduction

Conclusions References

Tables

Figures

14

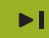

4

Back

\section{Full Screen / Esc}

Printer-friendly Version

Interactive Discussion 
BGD

4, 1059-1092, 2007

\section{Global warming potential of agro-ecosystems}

a)

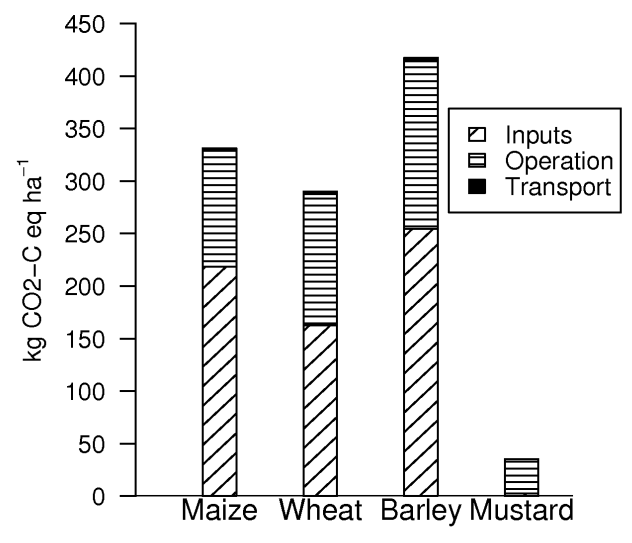

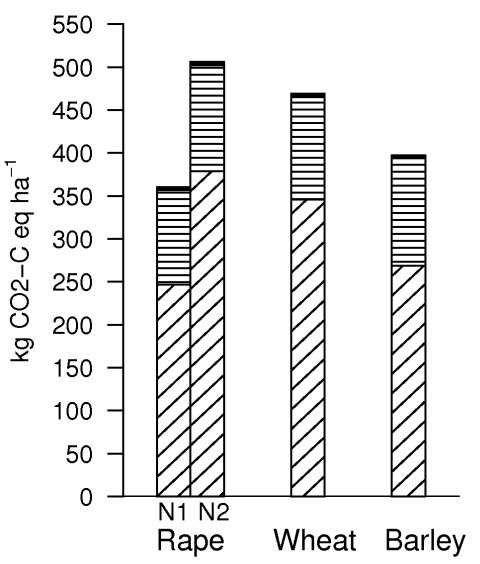

S. Lehuger et al.

Title Page

Abstract

Introduction

Conclusions

References

Tables

Figures

I4

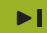

4

Back

Fig. 8. Greenhouse gas cost of agricultural inputs and cropping operations for crop production

(indirect emissions) for the Grignon (a) and Rafidin (b) cropping systems. The emissions are broken down into the input production, agricultural operations and transports steps.

\section{Full Screen / Esc}

Printer-friendly Version

Interactive Discussion 